\title{
Ground-Water Data for the Nevada Test Site, 1992, and for Selected Other Areas in South-Central Nevada, 1952-92
}

U.S. GEOLOGICAL SURVEY

Open-File Report 95-284

Prepared in cooperation with the NEVADA FIELD OFFICE,

U.S. DEPARTMENT OF ENERGY, under

Interagency Agreement DE-Al08-86NV10583

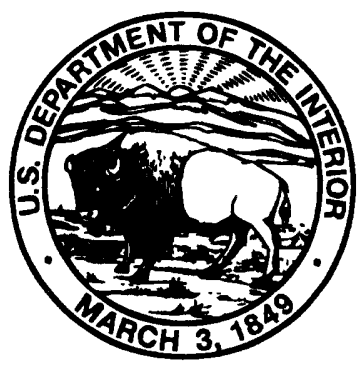




\section{Ground-Water Data for the Nevada Test Site, 1992, and for Selected Other Areas in South-Central Nevada, 1952-92}

By Leanne S. Robie, Steven R. Reiner, and Glenn L. Locke

U.S. GEOLOGICAL SURVEY

Open-File Report 95-284

Prepared in cooperation with the

NEVADA FIELD OFFICE,

U.S. DEPARTMENT OF ENERGY, under

Interagency Agreement DE-AI08-86NV10583

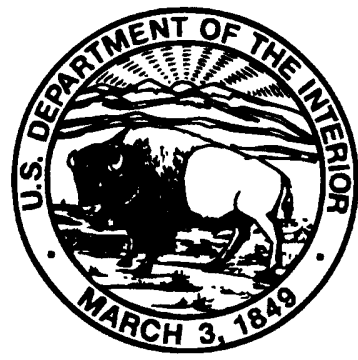

Carson City, Nevada 1995 


\title{
U.S. DEPARTMENT OF THE INTERIOR BRUCE BABBITT, Secretary
}

\author{
U.S. GEOLOGICAL SURVEY \\ Gordon P. Eaton, Director
}

Any use of trade names in this publication is for descriptive purposes only and does not constitute endorsement by the U.S. Government.

For additional information write to:

District Chief

U.S. Geological Survey 333 West Nye Lane, Room 203

Carson City, NV 89706-0866
Copies of this report can be purchased from:

U.S. Geological Survey

Information Services

Box 25286, MS 517

Denver Federal Center

Denver, CO 80225-0046 


\section{CONTENTS}

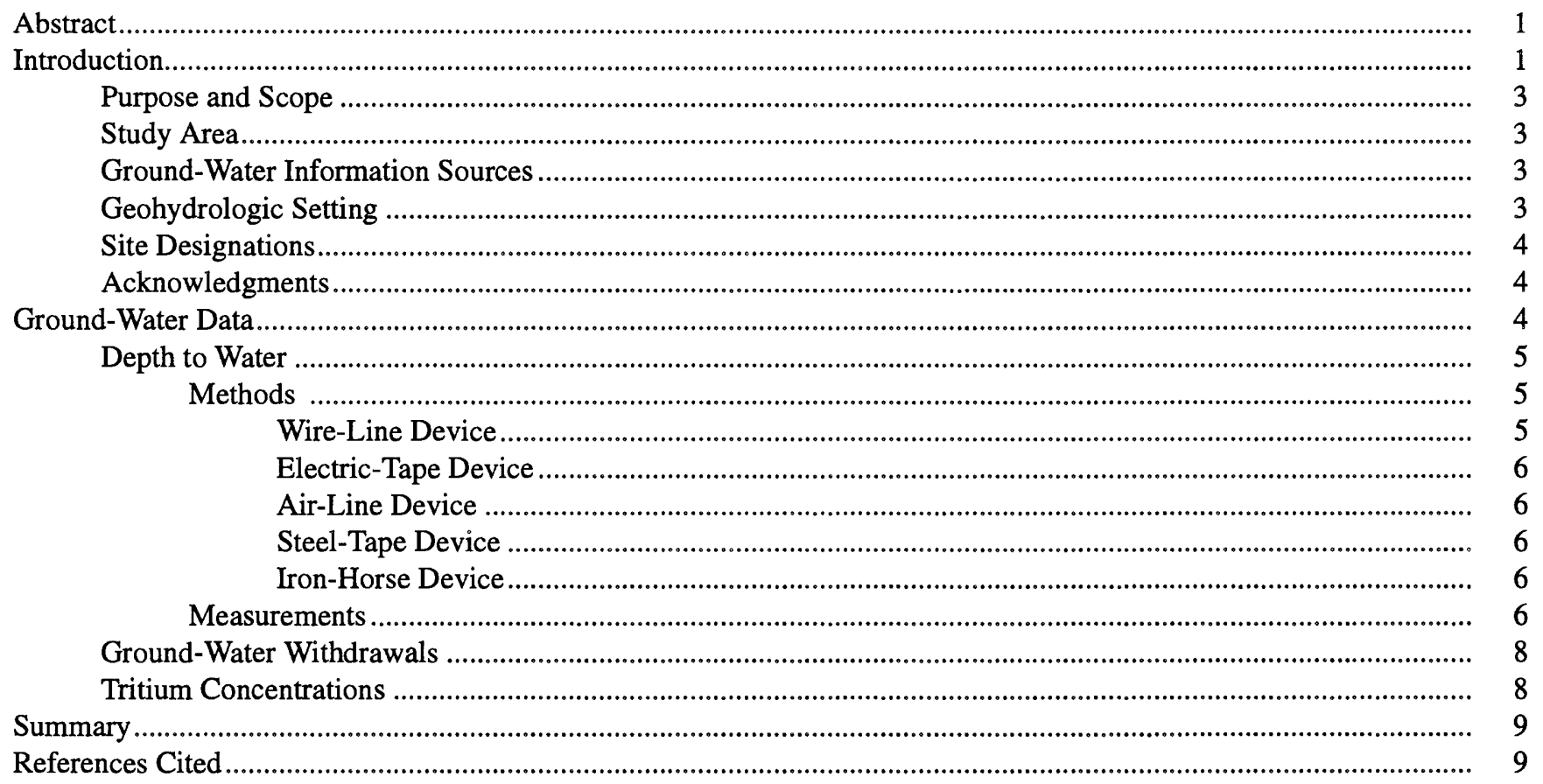

\section{PLATES}

Plate 1. Map showing location of wells and test holes at Nevada Test Site and vicinity, south-central Nevada

\section{FIGURES}

1. Map showing location of Nevada Test Site and vicinity, including Faultless Site............................................ 2

2. Map showing location of test holes at Faultless Site, Nye County, Nevada ........................................................ 3

3-11. Hydrographs showing depth to water through water year 1992 at Nevada Test Site in:

3. Well TW-7 in Yucca Flat hydrographic area (Area 3)

4. Test hole U-3cn 5 in Yucca Flat hydrographic area (Area 3)....................................................................... 12

5. Test hole UE-3e 4 in Yucca Flat hydrographic area (Area 3) ................................................................

6. Test hole UE-5n in Frenchman Flat hydrographic area (Area 5) ............................................................ 14

7. Test hole TW-B in Yucca Flat hydrographic area (Area 6) ....................................................................... 14

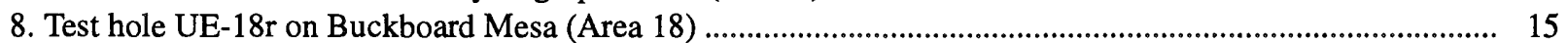

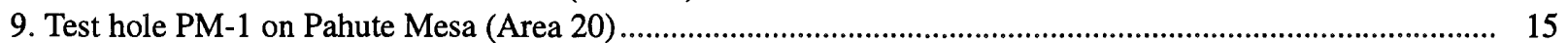

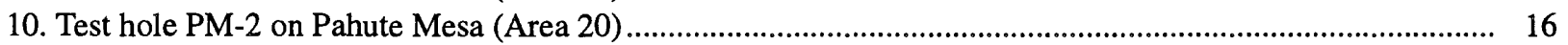

11. Well TW-F in Frenchman Flat hydrographic area (Area 27) ....................................................................... 16

12-18. Hydrographs showing depth to water through water year 1992 in vicinity of Nevada Test Site in:

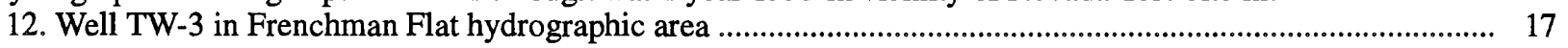

13. Test hole HTH-1 in Hot Creek Valley hydrographic area............................................................... 17

14. Test hole UC-1-P-2SR in Hot Creek Valley hydrographic area............................................................. 18

15. Well Army 2 in Indian Springs Valley hydrographic area .............................................................. 18

16. Well Army 3 in Indian Springs Valley hydrographic area ...................................................................... 19

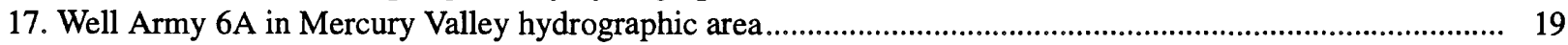

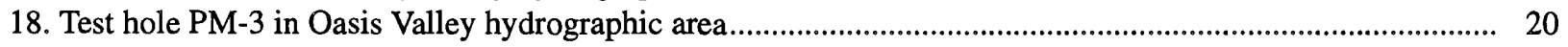

19. Graph showing annual ground-water withdrawals from Nevada Test Site, 1983-92 ........................................... 20 


\section{TABLES}

1. Depth to water in wells and test holes at Nevada Test Site, Nye County, Nevada .................................................... 21

2. Depth to water in wells and test holes in vicinity of Nevada Test Site, Nye and Clark Counties, Nevada..................... 33

3. Monthly and annual ground-water withdrawals in 1992 from wells at Nevada Test Site, Nye County, Nevada ............ 43

4. Tritium concentrations in water samples collected from test holes at Nevada Test Site, Nye County, Nevada .............. 48

\section{CONVERSION FACTORS AND ABBREVIATIONS}

\begin{tabular}{rll}
\hline Multiply & By & To Obtain \\
\hline foot (ft) & 0.3048 & meter \\
gallon (gal) & 3.785 & cubic decimeter \\
mile (mi) & 1.609 & kilometer \\
million gallons (Mgal) & 3.785 & million liters \\
picocurie (pCi) & 0.0370 & becquerel \\
square mile (mi $\left.{ }^{2}\right)$ & 2.590 & square kilometer \\
\hline
\end{tabular}

Sea Level: In this report "sea level" refers to the National Geodetic Vertical Datum of 1929 (NGVD, formerlly called "Sea-Level Datum of 1929"), which is derived from a general adjustment of the first order leveling networks of the United States and Canada.

Water Year: Comprises the 12-month period from October 1 through September 30, and is designated by the year in which the period ends. 


\title{
Ground-Water Data for the Nevada Test Site, 1992, and for Selected Other Areas in South-Central Nevada, 1952-92
}

\author{
By Leanne S. Robie, Steven R. Reiner, and Glenn L. Locke
}

\section{ABSTRACT}

The U.S. Geological Survey, in support of the U.S. Department of Energy Environmental Restoration and Hydrologic Resources Management Programs, collects and compiles hydrogeologic data to aid in characterizing the regional and local ground-water flow systems underlying the Nevada Test Site and vicinity. This report presents selected ground-water data collected from wells and test holes at and in the vicinity of the Nevada Test Site.

Depth-to-water measurements were made at 113 sites, 53 sites at the Nevada Test Site for the 1992 water year and 60 regional sites in the vicinity of the Nevada Test Site for 1952 through September 30, 1992. Depth to water ranged from 288 to 2,213 feet ( 87.8 to 674.5 meters) below land surface at the Nevada Test Site and from 22 to 1,460 feet ( 6.7 to 445.0 meters) below land surface at sites in the vicinity of the Nevada Test Site. Available historical data for sites outside boundaries of the Nevada Test Site show long-term depth-to-water fluctuations. Depth-to-water measurements were obtained using wire-line, electrictape, steel-tape, air-line, and iron-horse devices.

Total measured ground-water withdrawal from the Nevada Test Site during the 1992 calendar year was 595.313 million gallons $(2,253.26$ million liters). During the 1992 water year, tritium concentrations from five samples ranged from 0 to 166 picocuries per liter ( 0 to 6.14 becquerels per liter).

\section{INTRODUCTION}

The Nevada Test Site (fig. 1) was established in 1950 as a continental proving ground for testing nuclear weapons. Atmospheric nuclear testing began in 1951 and underground nuclear testing began in 1957. Since 1962, all nuclear testing has been done underground in mostly alluvium and volcanic rocks (U.S. Geological Survey, 1976, p. 17). Nuclear-testing and ancillary operations at the Nevada Test Site (NTS) have created the potential for contamination of ground-water supplies by radionuclides and other substances (U.S. Department of Energy, 1990, p. 110).

The U.S. Department of Energy (USDOE) is required to study potential ground-water contamination at NTS and, through its Environmental Restoration Program, has begun to define possible contamination resulting from past activities at NTS. The mission of the USDOE Hydrologic Resources Management Program (formerly Hydrology/Radionuclide Migration Program) is to ensure current activities proceed in an environmentally sound manner and in accordance with applicable Federal and State regulations and USDOE orders. The U.S. Geological Survey (USGS) provides hydrologic expertise and technical guidance to the USDOE in support of these programs. Specific responsibilities of the USGS include providing the necessary hydrologic and hydrogeologic data and interpretation of these data to aid in characterizing ground-water flow at NTS and vicinity. This characterization is needed to assess the potential for contamination of ground-water supplies and to support USDOE operations at NTS. 


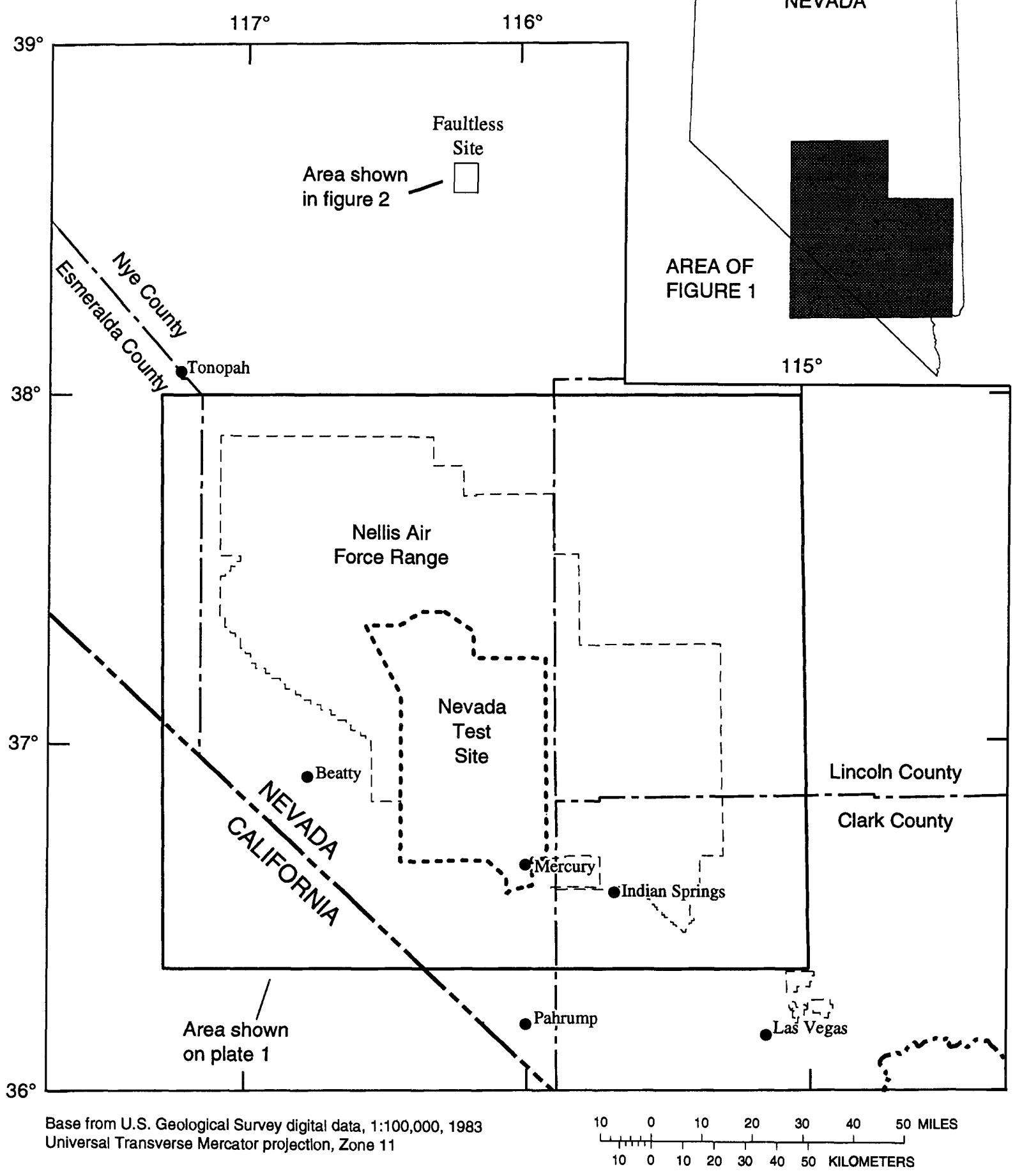

Figure 1. Location of Nevada Test Site and vicinity, including Faultless Site. 


\section{Purpose and Scope}

This report presents depth-to-water measurements made at 113 wells and test holes at and in the vicinity of NTS. At NTS, depths to water in 53 wells and test holes were measured from October 1, 1991, to September 30, 1992. Available historical data from 1952 to September 30, 1992, for 60 sites outside NTS boundaries are included. Hydrographs for sites at and in the vicinity of NTS are presented to show long-term depth-to-water fluctuations. Ground-water withdrawal data are compiled for 12 wells at NTS during the 1992 calendar year. Water samples were collected and analyzed for tritium concentrations from five test holes at NTS during the 1992 water year.
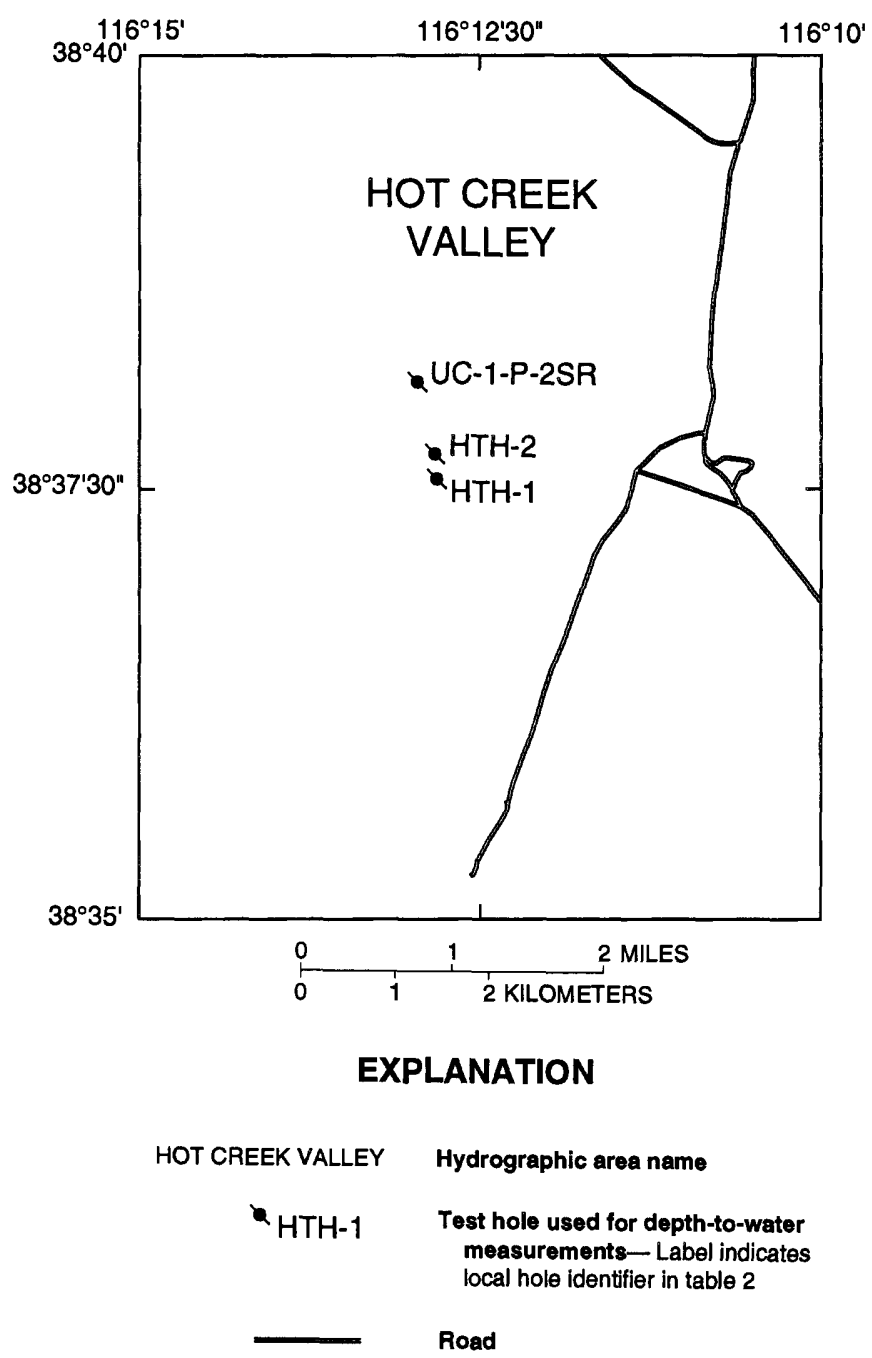

Figure 2. Location of test holes at Faultless Site, Nye County, Nevada.

\section{Study Area}

NTS is subdivided into 27 administrative areasbetween latitudes 36 and 38 degrees north and longitudes 115 and 117 degrees west within Nye County, Nev. (fig. 1, pl. 1). Regional ground-water sites in the vicinity of NTS are between latitudes 36 and 39 degrees north and longitudes 115 and 117 west within Clark and Nye Counties, Nev. (fig. 1; pl. 1). The Faultless Site in Hot Creek Valley is between latitudes 38 and 39 degrees north and longitudes 116 and 117 degrees west within Nye County, Nev. (figs. 1, 2).

\section{Ground-Water Information Sources}

Depth-to-water data at and in the vicinity of NTS have been collected, compiled, verified, and stored in the Ground-Water Site Inventory (GWSI) data base. The GWSI data base is one of four subsystems that constitute the computerized National Water-Information System (NWIS) of the USGS (U.S. Geological Survey, 1989), managed in Nevada by the District Office in Carson City.

The USDOE, Yucca Mountain Project study area is in and adjacent to Areas 25 and 29 of NTS (pl. 1). Ground-water data collected from these areas are compiled and reported by personnel of the USGS Hydrologic Investigation Program, Yucca Mountain Project (Luckey and others, 1989; O'Brien, 1991). However, ground-water withdrawal data for two wells in Area 25 (J-12 WW and J-13WW) also are included in this report as these wells contribute to the total withdrawal from NTS.

\section{Geohydrologic Setting}

The geohydrologic setting of NTS is similar to that of the Basin and Range Province. It is characterized by local aquifers of alluvium of Quaternary and Tertiary age and volcanic rock of Tertiary age. Regional aquifers are mainly complex folded and faulted carbonate rock of Paleozoic age (Winograd and Thordarson, 1975, p. 14-31), but deep, fractured volcanic rock of Tertiary age may be aquifers (Blankennagel and Weir, 1973, p. 6) at some locations. Regional confining units are mainly clastic rock of Paleozoic age and some volcanic rock of Tertiary age. Much of the 
ground-water movement is regional interbasin flow, which is not controlled by the basin-and-range topography that defines surface drainage basins (Winograd and Thordarson, 1975, p. 62).

Ground water at NTS and vicinity is part of the Death Valley ground-water flow system, a regional system encompassing $15,000 \mathrm{mi}^{2}\left(38,800 \mathrm{~km}^{2}\right)$. NTS includes parts of three subbasins of the Death Valley ground-water flow system-Alkali Flat-Furnace Creek Ranch, Ash Meadows, and Oasis Valley (Waddell and others, 1984, p. 36-39; R.J. Laczniak, U.S. Geological Survey, written commun., 1995; pl. 1).

\section{Site Designations}

Ground-water sites in this report are either wells or test holes: wells are cased holes drilled specifically to find ground water; test holes are all other drilled holes. Wells and test holes are identified herein by Raytheon Services Nevada (RSN) hole number or local well identifier, by USGS standard identification number, and by the latitude and longitude of the site.

Hole numbers are assigned by RSN to wells and test holes according to the type of hole drilled, site location (NTS administrative area), and sequence code for the consecutive order in which the hole was drilled or redrilled. Emplacement holes drilled for proposed nuclear testing begin with the letter " $U$," followed by a dash (-), NTS area number, and sequence code (letters "a-z, aa-az, ba-bz, ..., za-zz"). Exploratory holes, drilled to assess material properties within a defined area, follow the same naming convention, but begin with the letters "UE." The suffix letters "PS" indicate a post-shot hole drilled to monitor radionuclides and the effects of nuclear testing events; "S," a substitute hole drilled to replace an emplacement or exploratory hole; and "WW," a water well drilled as a potential water-supply source.

Exceptions to the standard naming convention are ER 12-1, PM-1, PM-2, RNM-2S, TW-1, TW-7, TW-B, TW-D, TW-F, WW-3, WW-4, and WW-5A. The prefix letters "ER" indicate environmental restoration; "PM," Pahute Mesa; "RNM," radionuclide migration; "TW," test well; and "WW," water well. Numbers and letters following the dash in these exceptions represent sequence of site drilling, not NTS area location.

Local hole identifiers for wells and test holes outside NTS are assigned by well owners or the USGS. These local hole identifiers may contain abbreviations that are the same as or similar to the ones found in RSN hole numbers for NTS wells and test holes. Abbreviations used in these hole identifiers that are not used at the NTS are "DDL" for Desert Dry Lake; "HTH," hydrologic test hole; "TTR," Tonopah Test Range; "TPJ," Tolicha Peak Junction; "UC," underground central Nevada; and "USAF," United States Air Force.

The U.S. Geological Survey system for siteidentification is based on the latitude-longitude grid. Each site is identified by a unique 15-digit number: The first six digits denote degrees, minutes, and seconds of latitude, the next seven digits denote degrees, minutes, and seconds of longitude, and the last two digits are the sequence number of the well or test hole within the 1 -second grid of latitude and longitude. The assigned number is retained as a permanent identifier even if a more precise latitude and longitude are later determined (U.S. Geological Survey, 1989, p. 2-10). To determine the geographic location of a well or test hole, the latitude and longitude coordinates should be used rather than the site identifier.

\section{Acknowledgments}

Raytheon Services Nevada and Atlas Wireline Services, contractors with the Nevada Field Office of the U.S. Department of Energy, made substantial contributions to this study, including field inventory of wells and test holes and other hydrologic work at NTS. Reynolds Electrical Engineering Co., Inc. (REECo) provided data on ground-water withdrawal. The Environmental Monitoring Systems Laboratory of the U.S. Environmental Protection Agency at Las Vegas performed the tritium analyses. Personnel of Nellis and Indian Springs Air Force Bases assisted in providing access and construction data for many off-site wells.

\section{GROUND-WATER DATA}

Data presented in this report consist of depth-towater measurements for accessible wells and test holes, compiled ground-water withdrawals for wells, and tritium concentrations for test holes. For water year 1992, depth-to-water measurements are reported for 53 wells and test holes. Ground-water withdrawals were compiled for 12 wells during the 1992 calendar year. Tritium concentrations were determined for water samples collected for five test holes during the 1992 
water year. Additionally, historical depth-to-water measurements for 60 wells and test holes in the vicinity of NTS are included.

Measurements were made in inch-pound units and converted to the International System of Units (SI). However, because of rounding in the conversion, values obtained by converting SI units back to inch-pound units may differ from the orginals. Values in a previous data report (Wood, 1992) are reported in inch-pound units only; those in any future reports will be reported in SI units. By reporting both inch-pound and SI units, this report serves as a transition between previous and any future reports.

Significant figures are retained in the conversion of inch-pound units to SI units. However, length measurements are reported to the nearest tenth of a meter to reflect the precision of field measurements.

\section{Depth to Water}

The term "depth to water" is used rather than "water level" to avoid confusion with "static water level" as defined by Winograd (1970, p. 19) for NTS. Use of depth to water does not imply static conditions.

Two networks of wells and test holes are measured-an NTS network and a regional network in the vicinity of NTS. Depth to water is measured intermittently in most of the accessible wells and test holes in these areas.

Measurements are made in new wells and test holes until the depth to water stabilizes, the hole is destroyed, or the hole becomes inaccessible due to testsite activities. Depth-to-water measurements in wells and test holes often represent elevated or depressed water levels caused by nearby underground detonations (Winograd, 1970 , p. 20-25) or injection or removal of fluids during drilling operations. Because most of the existing wells and test holes available for long-term monitoring were not drilled for the acquisition of hydrologic data, construction may allow several saturated units to contribute water to the wells and test holes. Depth-to-water fluctuations may represent a composite water level for multiple saturated units rather than conditions within a single aquifer unit (alluvium, volcanic-rock, or carbonate-rock aquifers).

Water-level altitudes, determined by subtracting depth-to-water measurements from the reported landsurface altitude, should be used with caution. The reported altitude of land surface is usually determined when drilling operations are completed. However, subsequent NTS activities may alter the land-surface datum. Changes in land-surface altitude, measuring point, or both, may affect depth-to-water measurements and the calculated water-level altitude.

\section{Methods}

Several techniques are used to measure depth to water at NTS and other areas in south-central Nevada. During 1992, measurements were made by the USGS with wire-line, electric-tape, air-line, and steel-tape devices. Measurements prior to 1992 were made with wire-line, electric-tape, air-line, steel-tape, and ironhorse devices. The accuracy and precision of methods and measurements are documented and maintained by the USGS.

The wire-line, electric-tape, steel-tape, and ironhorse devices were calibrated at least annually against a reference-steel tape. For these devices, a correction factor is determined to account for cable or tape stretch that occurs during measurement. The apparent depthto-water measurement is adjusted by the correction factor to obtain the depth to water. Each device is calibrated at different depths over the useful range of measurement of the device. The reference-steel tape is standardized by procedures of the National Institute of Standards and Technology (Taylor and Opperman, 1986).

A measuring point is established for each well or test hole. The measuring point is a permanent point on the well or test hole from which depth-to-water measurements are referenced. Measured depth to water is adjusted to land-surface datum by subtracting or adding the distance of the measuring point above or below land surface.

\section{Wire-Line Device}

The wire-line device consists of an armored, fourconductor cable mounted on a motorized reel. The cable is centered over the hole with a hydraulic boom. Attached to the cable end is a probe that transmits an electric current to a meter at land surface when water is contacted. A measuring wheel, over which the cable passes, measures the length of cable passed into the hole below the measuring point. The measured depth to water below the measuring point is corrected for cable stretch and adjusted to land-surface datum. 


\section{Electric-Tape Device}

The electric-tape device consists of a weighted electrical cable with two wire conductors exposed on the leading end. When both conductors contact water, electrical continuity between the two conductors is made and a visual display, sound beeper, or both, is activated. The measured depth to water below the measuring point is corrected for cable stretch and adjusted to land-surface datum.

\section{Air-Line Device}

The technique used for making air-line measurements of depth to water has been described by Garber and Koopman (1968, p. 11-14). The top of the air-line tube is connected to a motor-driven air compressor. Air pressure is increased in the air-line tube until all water in the tube has been expelled. Pressure stabilizes as the forced air pressure gradient in the air-line tube decreases with increasing water pressure. Gage readings indicate the length of the column of water expelled from the air line, either directly in feet of water or indirectly through pressure readings. To calculate the depth to water, the length of the column of expelled water is subtracted from the length of the air-line tube. Measured depth to water is adjusted to land-surface datum by subtracting or adding the distance of the airline reference point above or below land surface.

\section{Steel-Tape Device}

The technique used for making steel-tape measurements of depth to water greater than $1,000 \mathrm{ft}$ $(305 \mathrm{~m})$ below land surface is described by Garber and Koopman (1968, p. 2-6) and Robison and others (1988, p. 9-11). The steel tape, which is mounted on a motorized reel, is suspended in the hole a known distance below the measuring point so the bottom end is below the water surface. The length of wetted tape is subtracted from the suspended length below the measuring point and adjusted to land-surface datum.

\section{Iron-Horse Device}

The technique for using the iron-horse device to measure depth to water has been described by Garber and Koopman (1968, p. 6-11) and Weir and Nelson (1976). The device consists of an armored, singleconductor cable mounted on a portable reel. Attached to the cable end is a probe that transmits an electric cur- rent to a meter at land surface when water is contacted. A measuring wheel, over which the cable passes, measures the length of cable lowered into the hole below a measuring point. The measured depth to water below this measuring point is corrected for cable stretch and adjusted to land-surface datum.

\section{Measurements}

Depth-to-water measurements at 53 wells and test holes at NTS made during water year 1992 are listed in table 1. Depth-to-water measurements for 60 wells in the vicinity of NTS made from 1952 through September 30,1992, are shown in table 2. Data are organized in table 1 first by NTS administrative area, then by RSN hole-number designation within each area. Data are organized in table 2 by Nevada hydrographic area (Rush, 1968) and then by local well identifier. Tables 1 and 2 also include well location and construction information.

Depth to water ranged from 288 to $2,213 \mathrm{ft}(87.8$ to $674.5 \mathrm{~m}$ ) below land surface at NTS and from 22 to $1,460 \mathrm{ft}(6.7$ to $445.0 \mathrm{~m})$ below land surface at sites in the vicinity of NTS for water year 1992. Depth-towater measurements made prior to October 1, 1989, for wells at the Faultless Site were reported by Wood (1992). All data have been entered into the GWSI data base.

The information available for some wells and test holes listed in tables 1 and 2 is incomplete. Dates for which the month or day are unknown are listed as "00." To indicate that other information is unknown or not applicable, one or two dashes are shown.

In this report, values for date hole completed and hole depth may differ from values reported by RSN or other agencies. The date of hole completion shown in tables 1 and 2 is the date when drilling activities that may have affected water levels ceased. The date of hole completion is not the reported date that construction activities at the hole ceased. The hole depth is the most recently available measured or reported accessible depth. For some holes, the bottom of open interval listed in tables 1 and 2 may be deeper than the hole depth listed. This is because the bottom of open interval is reported at the time of well or test-hole installation, but the hole depth is the latest accessible depth measured or reported.

The terms active testing area and inactive testing area refer to the approximate extent of areas where nuclear testing occurred. Active testing areas are areas 
where nuclear testing occurred during or after 1982. Inactive testing areas are areas where nuclear testing occurred prior to 1982 .

Nine hydrographs of wells and test holes at NTS (figs. 3-11) and seven hydrographs of wells in the vicinity of NTS (figs. 12-18) show changes in depth to water with time. These selected hydrographs are from wells in several geographic areas and rock types. All available depth-to-water measurements for these hydrographs are displayed. Some of the pre-1992 depth-towater measurements at NTS are presented by Wood (1992) or can be retrieved from the GWSI data base.

Depth-to-water measurements in well TW-7, which is in an active testing area in the Yucca Flat hydrographic area (Area 3, pl. 1), are shown in figure 3 . The well is open to Tertiary volcanic rock, primarily tuff. Two minimum depth-to-water measurements were recorded, one on June 12, 1962, and one on September 13,1963 . These peaks coincide with two nuclear detonations - the Aardvark event $1,008 \mathrm{ft}(307 \mathrm{~m})$ east of TW-7 on May 12, 1962, and the Bilby event 3,850 ft $(1,173 \mathrm{~m})$ east-southeast TW-7 on September 13, 1963 (U.S. Department of Energy, 1988).

Depth-to-water measurements in test hole $\mathrm{U}-3 \mathrm{cn} 5$, which is in an active testing area in the Yucca Flat hydrographic area (Area 3, pl. 1), are shown in figure 4. The test hole is open to Paleozoic carbonate rock.

Depth-to-water measurements in test hole UE-3e4, which is in an active testing area in the Yucca Flat hydrographic area (Area 3, pl.1), are shown in figure 5. The site is composed of three piezometers open to Tertiary volcanic rock at different depths.

Depth-to-water measurements in test hole UE-5n, which is in an inactive testing area in the Frenchman Flat hydrographic area (Area 5, pl. 1), are shown in figure 6. The well is open to Quaternary alluvium.

Depth-to-water measurements in well TW-B, which is in an area of active testing in the Yucca Flat hydrographic area (Area 6, pl. 1), are shown in figure 7. The well is open to Tertiary volcanic rock, primarily tuff.

Depth-to-water measurements in test hole UE-18r on Buckboard Mesa in the Fortymile Canyon hydrographic area (Area 18, pl.1) are shown in figure 8. The test hole is open to Tertiary volcanic rock, primarily tuff.
Depth-to-water measurements in test hole PM-1, which is in an active area of testing on Pahute Mesa in the Gold Flat hydrographic area (Area 20, pl. 1), are shown in figure 9. The test hole is open to Tertiary volcanic rock, primarily tuff and rhyolite.

Depth-to-water measurements in test hole PM-2, which is in an active testing area on Pahute Mesa in the Gold Flat hydrographic area (Area 20, pl. 1), are shown in figure 10 . The test hole is open to Tertiary volcanic rock, primarily tuff, rhyolite, and dacite.

Depth-to-water measurements in well TW-F in the Frenchman Flat hydrographic area (Area 27, p1. 1) are shown in figure 11. The well is open to Paleozoic carbonate rock, primary dolomite.

Depth-to-water measurements in Test Well 3 in the Frenchman Flat hydrographic area (pl. 1) are shown in figure 12. The well is open to Paleozoic carbonate rock.

Depth-to-water measurements in HTH-1 in the Hot Creek Valley hydrographic area (fig. 2) are shown in figure 13. The test hole is open to Quaternary and Tertiary alluvium and Tertiary volcanic rock, primarily tuff and tuffaceous sediments. The minimum depth-towater measured was on January 22, 1968, only 3 days after a nuclear test, the Faultless event, on January 19 , 1968. The Faultless event occurred 3,002 ft (915 m) northwest of HTH-1 (U.S. Department of Energy, 1988).

Depth-to-water measurements in test hole UC-1P-2SR in the Hot Creek Valley hydrographic area (fig. 2) are shown in figure 14. The test hole is open to rubble consisting of Quaternary and Tertiary alluvium and Tertiary volcanic rock, primarily tuff, caused by the collapse of the cavity formed by the Faultless event $299 \mathrm{ft}$ (91 m) northeast of UC-1-P-2SR (Garber, 1981, p. 207-209). Decreases in depth to water from September 1974 to present (1992) are attributed to infilling of the cavity (Thordarson, 1987, p. 15-16).

Depth-to-water measurements in well Army 2 in the Indian Springs Valley hydrographic area (pl. 1) are shown in figure 15 . The well is open to Quaternary and Tertiary alluvium.

Depth-to-water measurements in well Army 3 in the Indian Springs Valley hydrographic area (pl. 1) are shown in figure 16. The well is open to Quaternary and Tertiary alluvium.

Depth-to-water measurements in well Army 6A in the Mercury Valley hydrographic area (pl. 1) are shown in figure 17 (pl.2). The well is open to Paleozoic clastic rock. 
Depth-to-water measurements in test hole PM-3 on Pahute Mesa in the Oasis Valley hydrographic area (pl. 1) are shown in figure 18. The test hole is open to Tertiary volcanic rock, primarily tuffs. Measurements prior to September 14, 1988, were made when the hole depth was $1,647 \mathrm{ft}$ (502.0 m). Measurements from September 21, 1988, through 1991 were made when the hole depth was 3,019 ft $(920.2 \mathrm{~m})$. Measurements during 1992 were made from two piezometers installed in February 1992 at depths of 1,667 and 2,144 ft (508.1 and $653.5 \mathrm{~m}$ ).

\section{Ground-Water Withdrawals}

Ground-water withdrawals at NTS were compiled for calendar year 1992. Withdrawals were measured by REECo at 12 pumping wells used for water supply at NTS. The compilation does not include ground water removed from other wells and test holes as a result of drilling, hydrologic testing, or sampling activities.

Withdrawals were determined from flowmeter and ammeter information. Each well is equipped with a totalizing flowmeter that is periodically read by REECo personnel. Differences between flowmeter readings provide the volume of ground water withdrawn during the period between readings. Flow rates were assumed to be constant during the period between readings. Daily withdrawal was computed from the total calculated volume of withdrawal. Flowmeter readings are accurate to the last thousand gallons pumped. Ammeter data provided pump on and off times and were used when flowmeter information was not available.

Monthly and yearly ground-water withdrawals from wells at NTS are shown in table 3. The table lists wells by NTS administrative area and then by RSN hole-number designation. Primary water yielding units and location and construction data are listed in table 3.

Annual ground-water withdrawals from individual wells during 1992 ranged from 5.284 Mgal (20.00 million liters) to $139.420 \mathrm{Mgal}$ (527.71 million liters) (table 3). Total measured ground-water withdrawal from NTS was 595.313 Mgal (2,253.26 million liters).

Ground-water at NTS is withdrawn from alluvium, volcanic rock, and carbonate rock (table 3). At NTS in the Alkali Flat-Furnace Creek Ranch subbasin, ground water is withdrawn from volcanic rock and in Ash Meadows subbasin, it is withdrawn from all three rock units. About 59 percent of withdrawal from the Ash Meadows subbasin was from carbonate rock, 23 percent from volcanic rock, 17 percent from alluvium, and 1 percent from a well open to both alluvium and volcanic rocks. Wells at NTS in the Oasis Valley subbasin had no withdrawals.

Annual ground-water withdrawals at NTS from 1983 through 1992 are shown in figure 19. Total ground-water withdrawals decreased from 1,117.466 Mgal (4,229.61 million liters) in 1989 to $595.313 \mathrm{Mgal}$ $(2,253.26$ million liters) in 1992 . About 60 percent of the total decrease in ground-water withdrawal from 1989 through 1992 was caused by decreasing withdrawals from well RNM-2S, which discontinued operation in 1991.

\section{Tritium Concentrations}

Raw, unfiltered water samples were collected from five test holes at NTS by using a wire-line point sampler. Prior to sampling, the collection bailer was rinsed with tap and deionized water, air dried, and then used to remove approximately $1 / 2 \mathrm{gal}(2 \mathrm{~L})$ of water from the test hole. Samples were collected in 1-L glass bottles. The Environmental Monitoring Systems Laboratory of the U.S. Environmental Protection Agency in Las Vegas, Nev., analyzed the samples for tritium concentration.

Location and construction information, tritium concentrations, and collection depths for the sampled test holes are presented in table 4 . This table lists test holes at NTS by administrative area number. Because some of the test holes may have not been completely developed for water-quality sampling use, tritium concentrations may be from residual drilling fluids or other fluids introduced during drilling, pumping, or water injection instead of representing water solely from the saturated zone.

Tritium concentrations ranged from near 0 to 166 $\mathrm{pCi} / \mathrm{L}$ (0 to $6.14 \mathrm{~Bq} / \mathrm{L}$ ) from five wells sampled at NTS during water year 1992. An average annual concentration of $20,000 \mathrm{pCi} / \mathrm{L}(740 \mathrm{~Bq} / \mathrm{L})$ of tritium in drinking water is the maximum permissible limit established by the U.S. Environmental Protection Agency in Title 40, Code of Federal Regulations (1988). None of the tritium concentrations exceeded this limit. 


\section{SUMMARY}

The USGS, in support of the USDOE Environmental Restoration and Hydrologic Resources Management Programs, collects and compiles hydrogeologic data to aid in characterizing the regional and local ground-water flow systems at NTS and vicinity. This report presents data on depth to water, groundwater withdrawals, and tritium concentrations for selected wells and test holes.

Depth-to-water measurements were made at 53 sites at NTS during the 1992 water year and ranged from 288 to $2,213 \mathrm{ft}$ ( 87.8 to $674.5 \mathrm{~m}$ ) below land surface. Depth-to-water measurements were made at 60 regional sites in the vicinity of NTS from 1952 through September 30,1992, and ranged from 22 to $1,460 \mathrm{ft}$ $(6.7$ to $445.0 \mathrm{~m}$ ) below land surface. Annual groundwater withdrawals from 12 wells at NTS ranged from 5.284 to $139.420 \mathrm{Mgal}$ (20.00 to 527.71 million liters) per well. Total annual ground-water withdrawal from NTS during the 1992 calendar year was $595.313 \mathrm{Mgal}$ $(2,253.26$ million liters). Tritium concentrations of five ground-water samples collected at NTS during the 1992 water year ranged from near 0 to $166 \mathrm{pCi} / \mathrm{L}$ ( 0 to 6.14 Bq/L) and did not exceed established drinking water standards.

\section{REFERENCES CITED}

Blankennagel, R.K., and Weir, J.E., Jr., 1973, Geohydrology of the eastern part of Pahute Mesa, Nevada Test Site, Nye County, Nevada: U.S. Geological Survey Professional Paper 712-B, 35 p.

Garber, M.S., 1981, A method for estimating effective porosity in a rubble chimney formed by an underground nuclear explosion, in Geological Survey Research, 1971: U.S. Geological Survey Professional Paper 750-C, p. 207-209.

Garber, M.S., and Koopman, F.C., 1968, Methods of measuring water levels in deep wells: U.S. Geological Survey Techniques of Water-Resources Investigations, Book 8, Chapter A1, 23 p.

Luckey, R.R, Lobmeyer, D.H., and Burkhardt, D.J., 1989, Water levels in continuously monitored wells in the Yucca Mountain area, Nevada, 1985-88: U.S. Geological Survey Open-File Report 91-493, 252 p.

O'Brien, G.M., 1991, Water levels in periodically measured wells in the Yucca Mountain area, Nevada, 1989: U.S. Geological Survey Open-File Report 91-178, 51 p.
Robison, J.H., Stephens, D.M., Luckey, R.R., and Baldwin, D.A., 1988, Water levels in periodically measured wells in the Yucca Mountain area, Nevada, 1981-87: U.S. Geological Survey Open-File Report 88-468, 132 p.

Rush, F.E., 1968, Index of hydrographic areas in Nevada: Nevada Division of Water Resources, Information Report 6, 38 p.

Taylor, J.D., and Opperman, H.V., 1986, Handbook for the quality assurance of meteorological measurements: U.S. Department of Commerce, National Bureau of Standards, NBS Handbook 145, SOP 11, 16 p.

Thordarson, William, 1987, Hydrogeology of the Faultless Site, Nye County, Nevada: U.S. Geological Survey Water-Resources Investigations Report 86-4342, 40 p.

U.S. Department of Energy, 1988, Announced United States nuclear tests, July 1945 through December 1987: Nevada Operations Office, Office of Public Affairs Report NVO-209, Revision 8, 66 p.

1990 , Environmental restoration and waste management-Five year plan, fiscal years 1992-96: Washington, D.C., U.S. Government Printing Office, 622 p.

U.S. Environmental Protection Agency, 1988, Title 40, Section 141, Drinking Water Regulations: Federal Register, U.S. Code of Federal Regulations, v. 41.

U.S. Geological Survey, 1976, Field trip to Nevada Test Site: U.S. Geological Survey Open-File Report 76-313, 64 p.

1989 , National water information system user's manual, v. 2, ch. 4--Ground-water site inventory system: U.S. Geological Survey Open-File Report 89-587, $293 \mathrm{p}$.

Waddell, R.K., Robison, J.H., and Blankennagel, R.K., 1984, Hydrology of Yucca Mountain and vicinity, Nevada-California-Investigative results through mid-1983: U.S. Geological Survey Water-Resources Investigations Report 84-4267, 72 p.

Weir, J.E., Jr., and Nelson, J.W., 1976, Operation and maintenance of a deep-well water-level measurement device,"the iron horse": U.S. Geological Survey WaterResources Investigations 76-27, 28 p.

Winograd, I.J., 1970, Noninstrumental factors affecting measurement of static water levels in deeply buried aquifers and aquitards, Nevada Test Site: Ground Water, v. 8, no. 2, p. 19-28.

Winograd, I.J., and Thordarson, William, 1975, Hydrogeologic and hydrochemical framework, south-central Great Basin, Nevada-California, with special reference to the Nevada Test Site: U.S. Geological Survey Professional Paper 712-C, $126 \mathrm{p}$.

Wood, D.B., 1992, Ground-water data collected at the Nevada Test Site and vicinity, Nye County, Nevada, water years 1988-89: U.S. Geological Survey OpenFile Report 92-130, 50 p. 


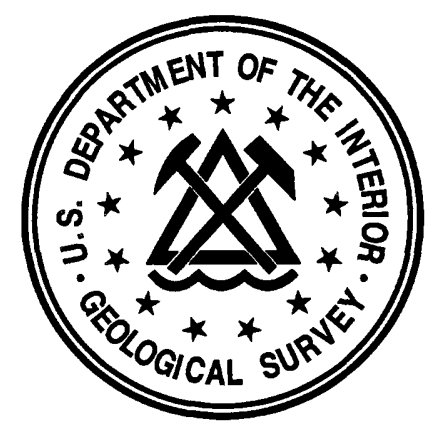




\section{BASIC DATA}




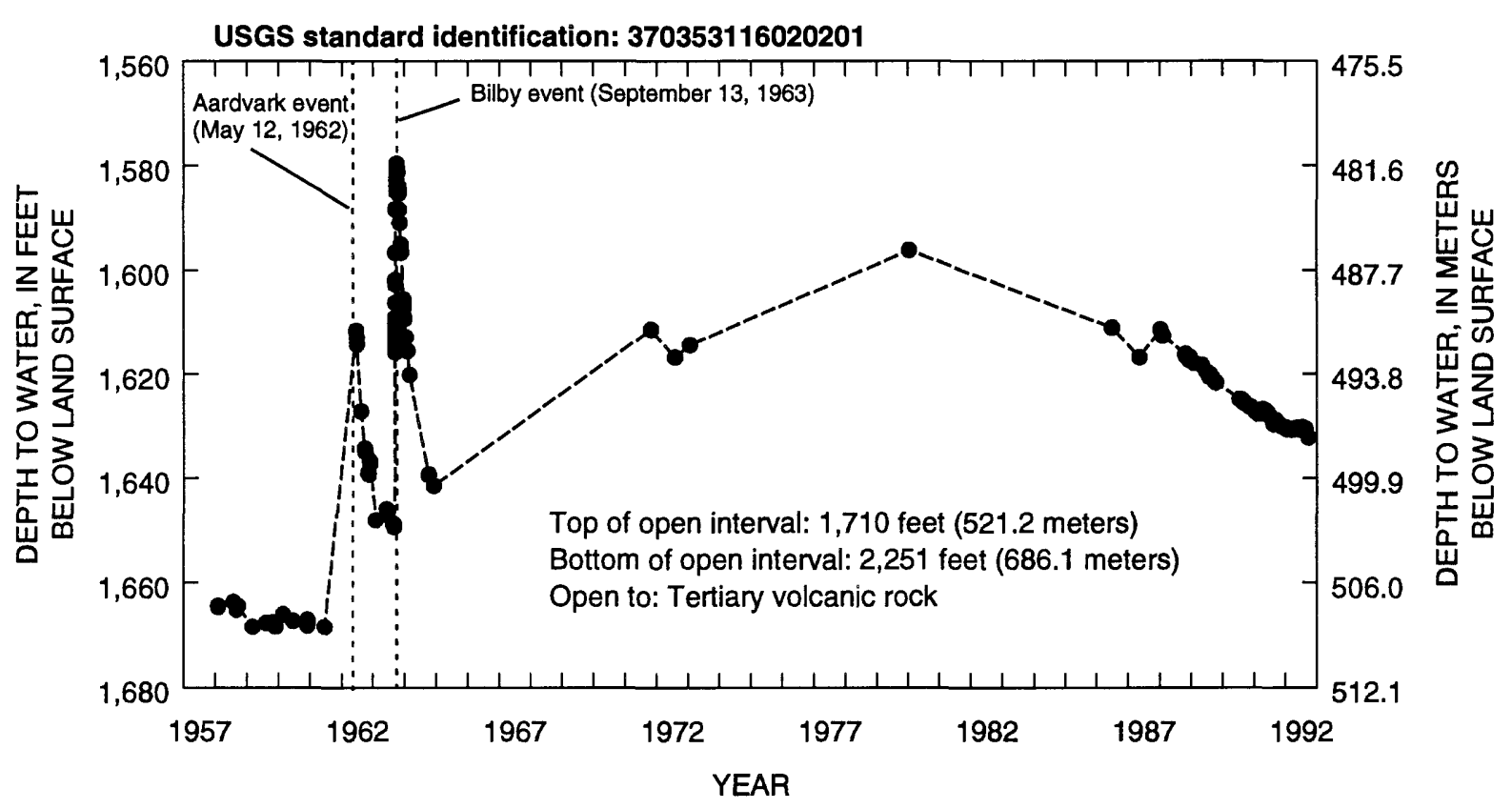

Figure 3. Depth to water through water year 1992 in well TW-7 in Yucca Flat hydrographic area (Area 3), Nevada Test Site. Names and dates are indicated for nearby nuclear tests.

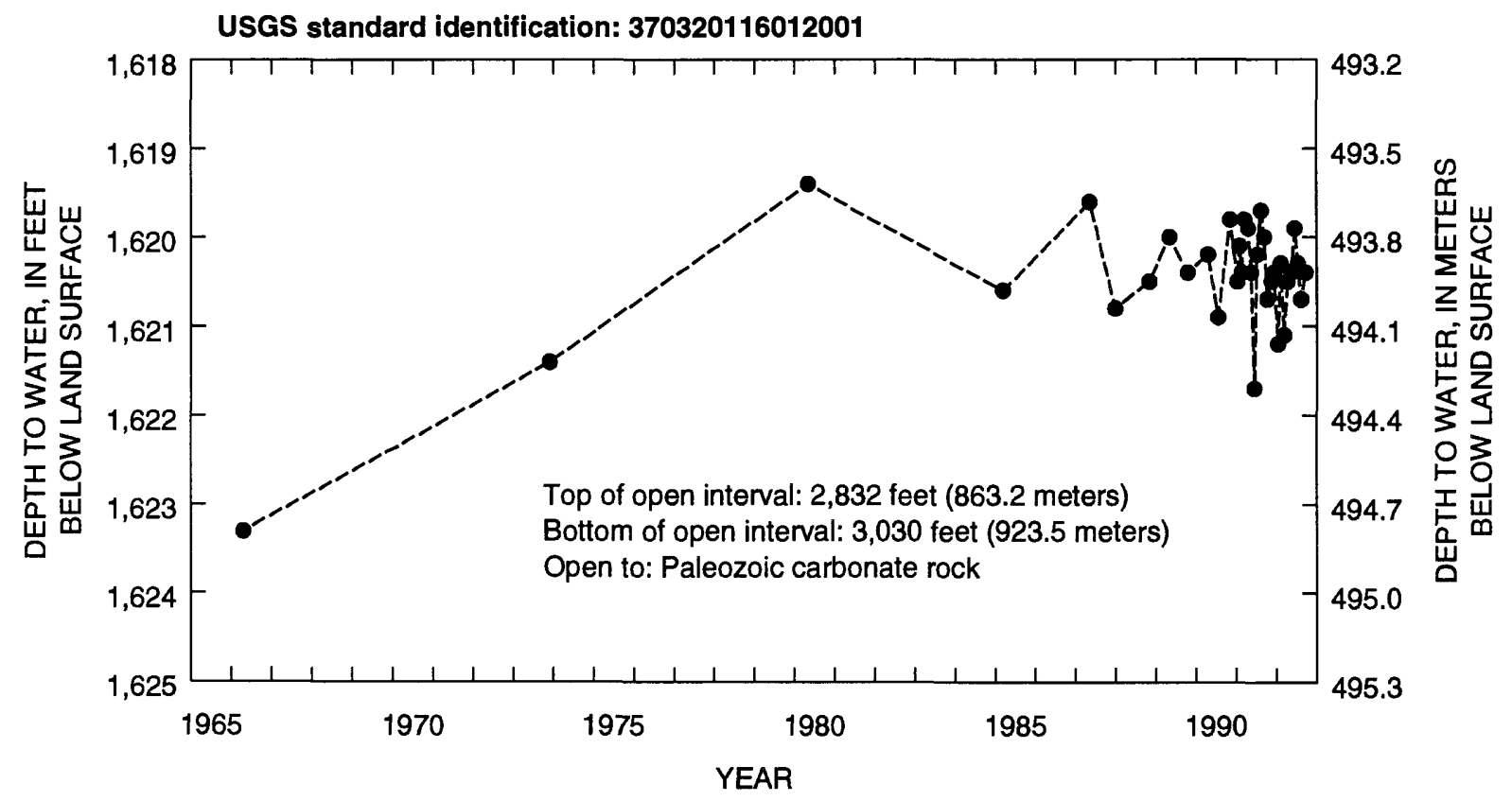

Figure 4. Depth to water through water year 1992 in test hole U-3cn 5 in Yucca Flat hydrographic area (Area 3), Nevada Test Site. 


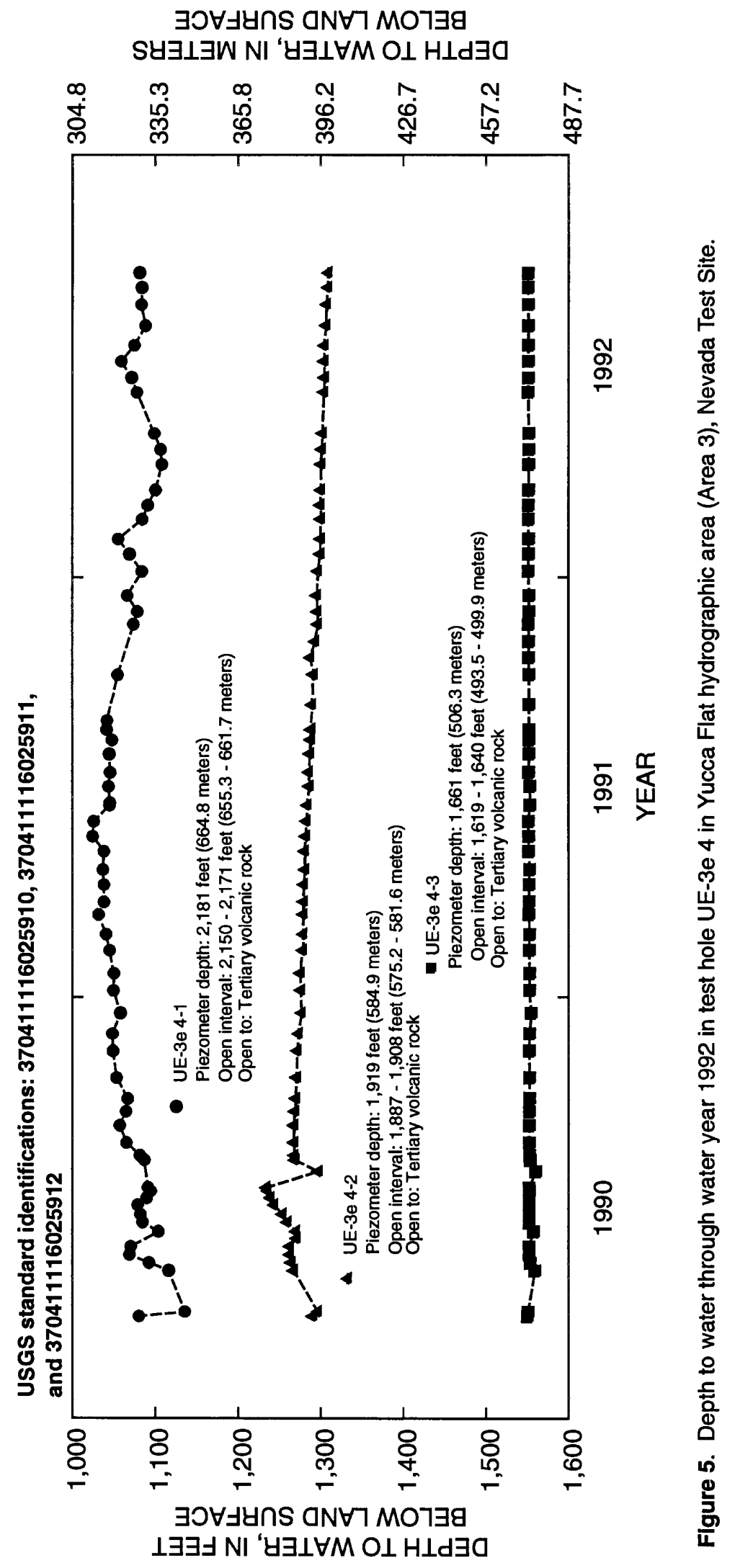




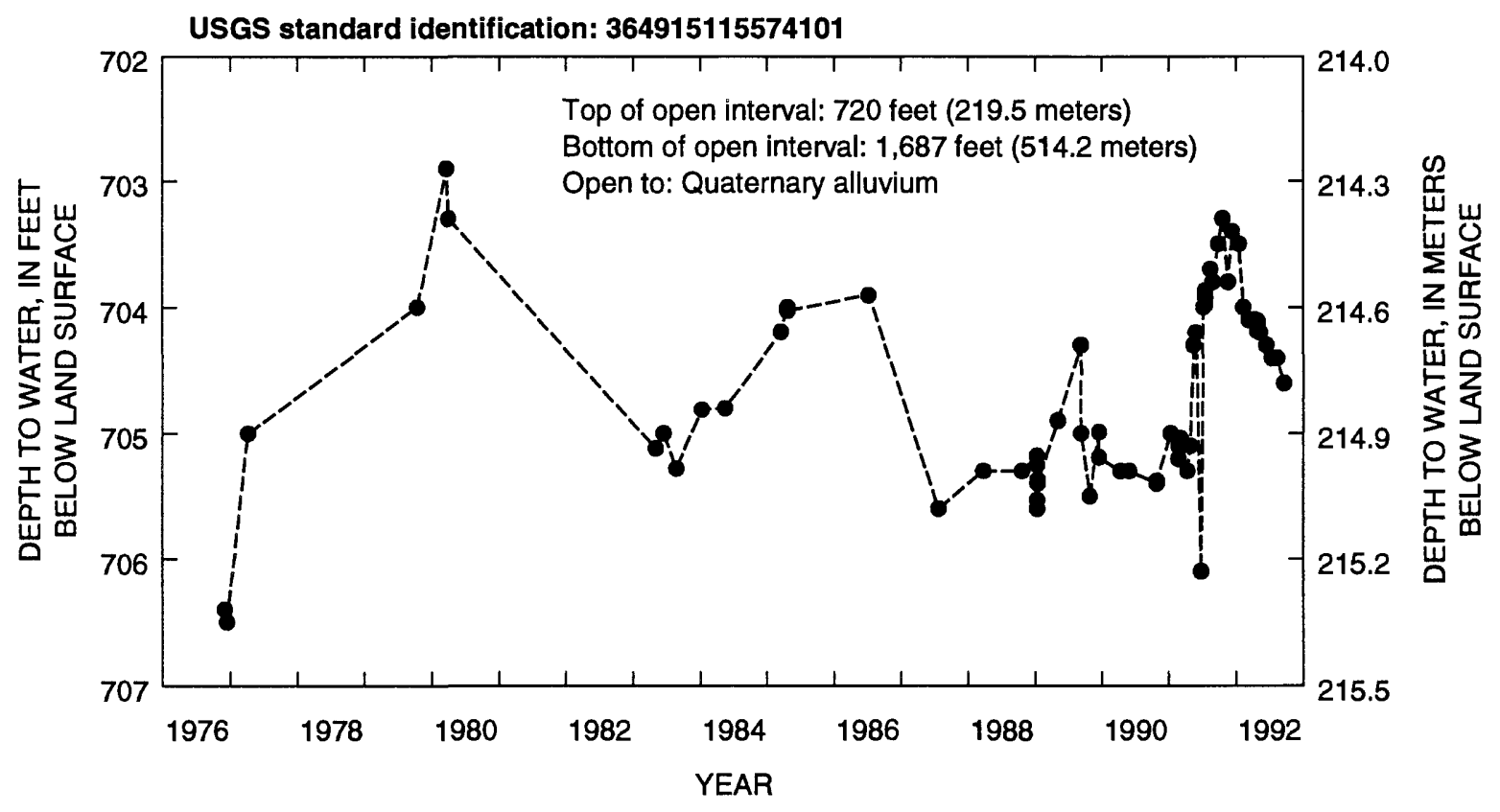

Figure 6. Depth to water through water year 1992 in test hole UE-5n in Frenchman Flat hydrographic area (Area 5), Nevada Test Site.

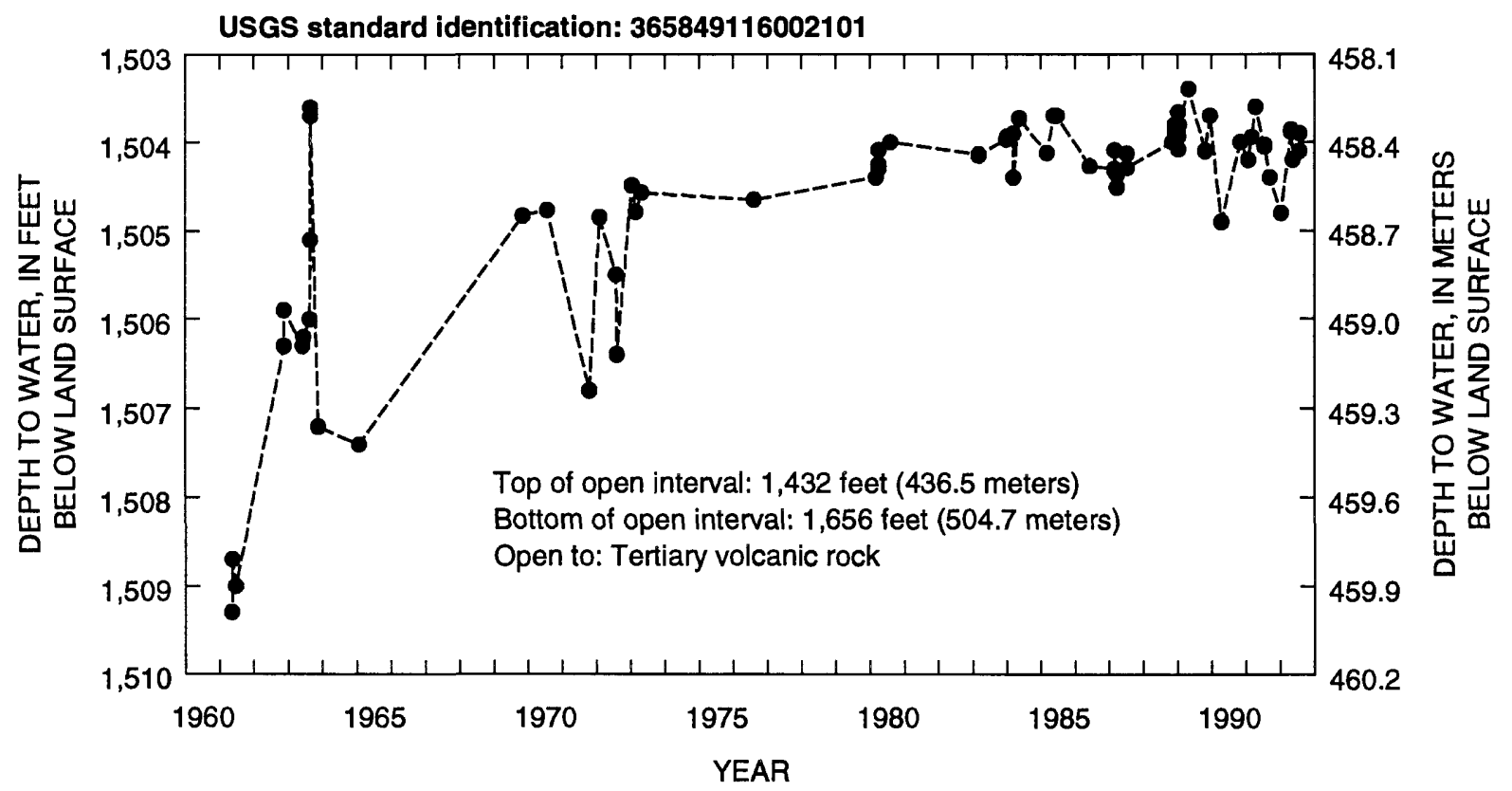

Figure 7. Depth to water through water year 1992 in test hole TW-B in Yucca Flat hydrographic area (Area 6), Nevada Test Site. 


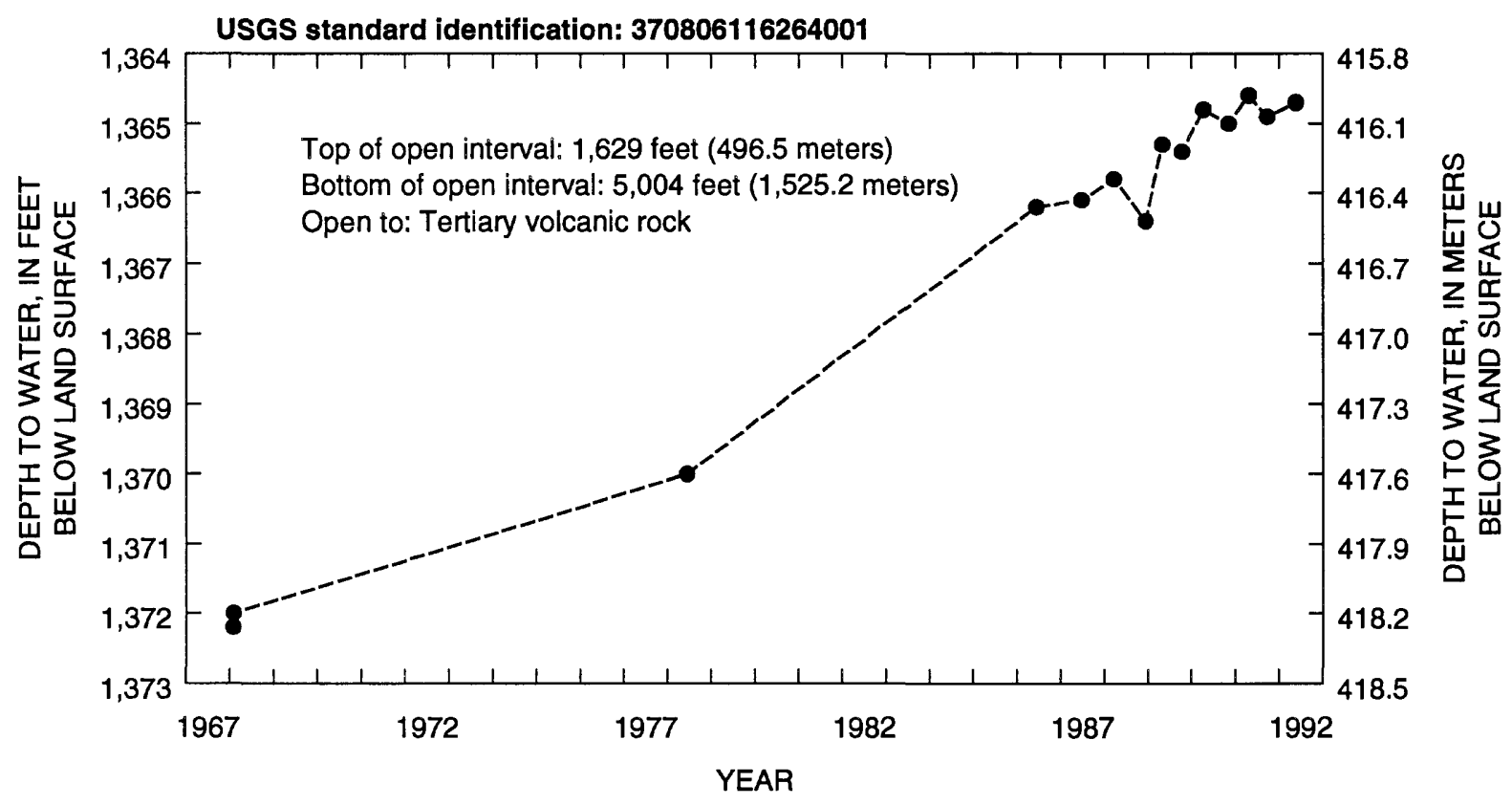

Figure 8. Depth to water through water year 1992 in test hole UE-18r on Buckboard Mesa (Area 18), Nevada Test Site.

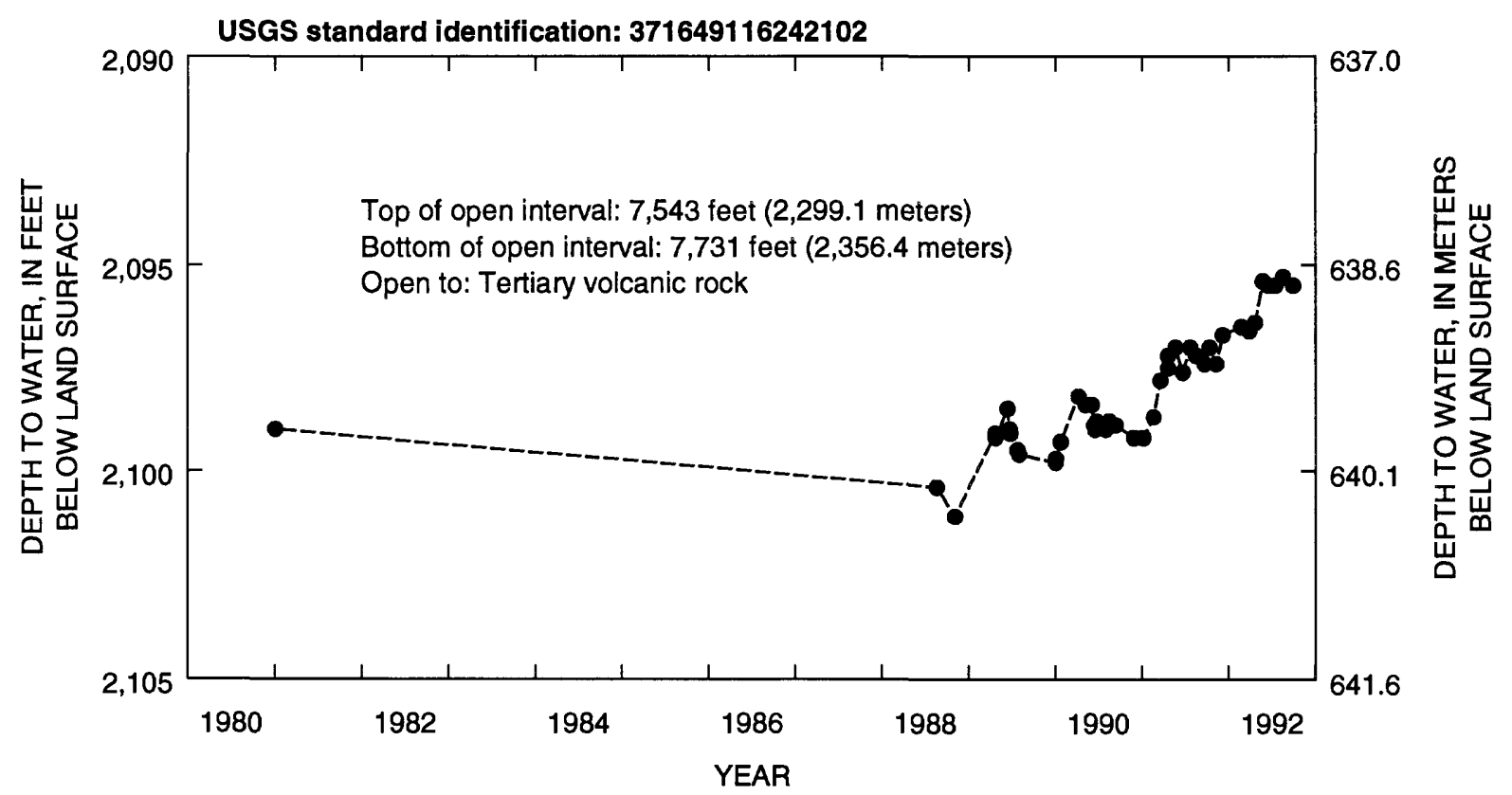

Figure 9. Depth to water through water year 1992 in test hole PM-1 on Pahute Mesa (Area 20), Nevada Test Site. 


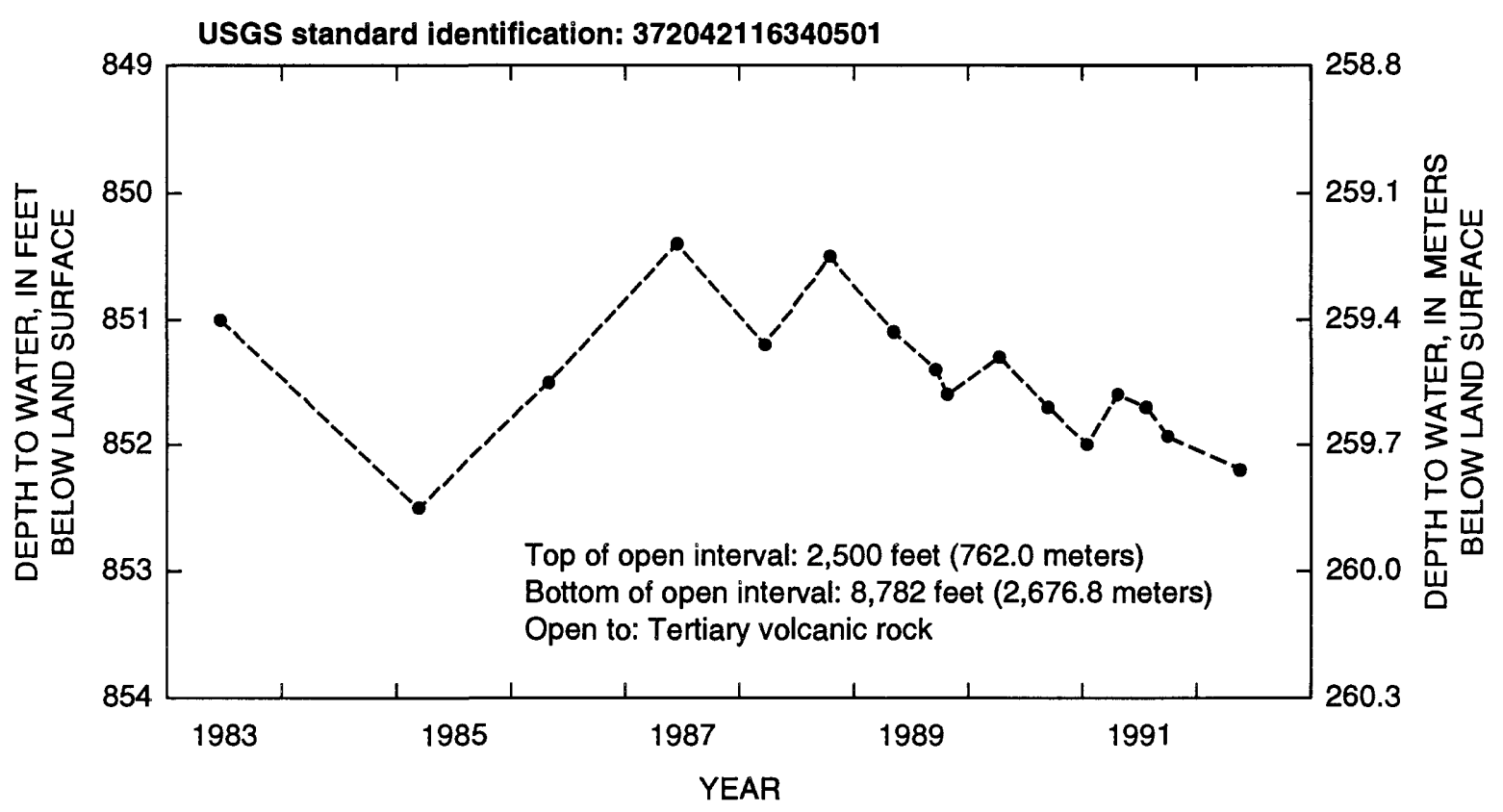

Figure 10. Depth to water through water year 1992 in test hole PM-2 on Pahute Mesa (Area 20), Nevada Test Site.

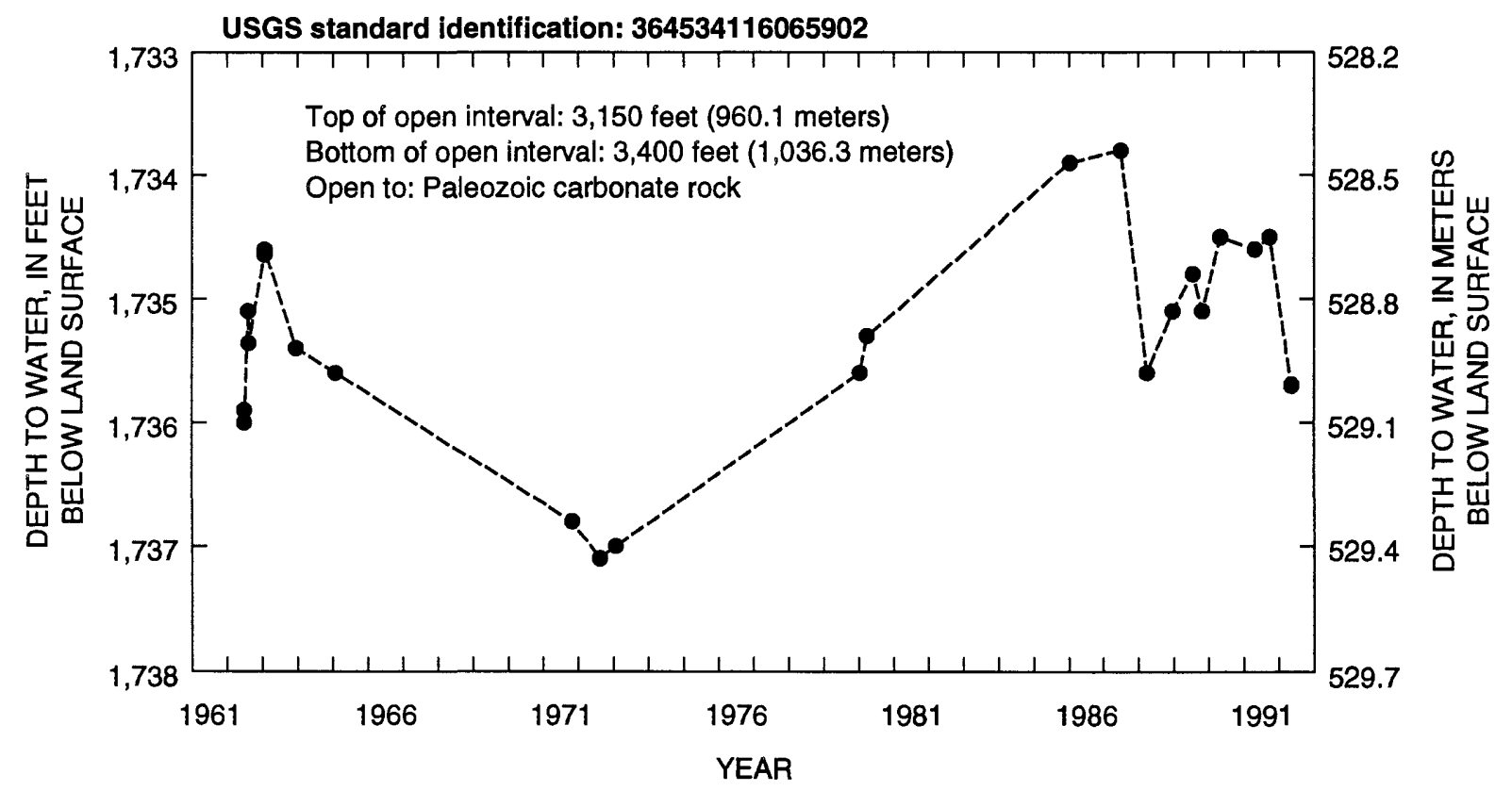

Figure 11. Depth to water through water year 1992 in well TW-F in Frenchman Flat hydrographic area (Area 27), 


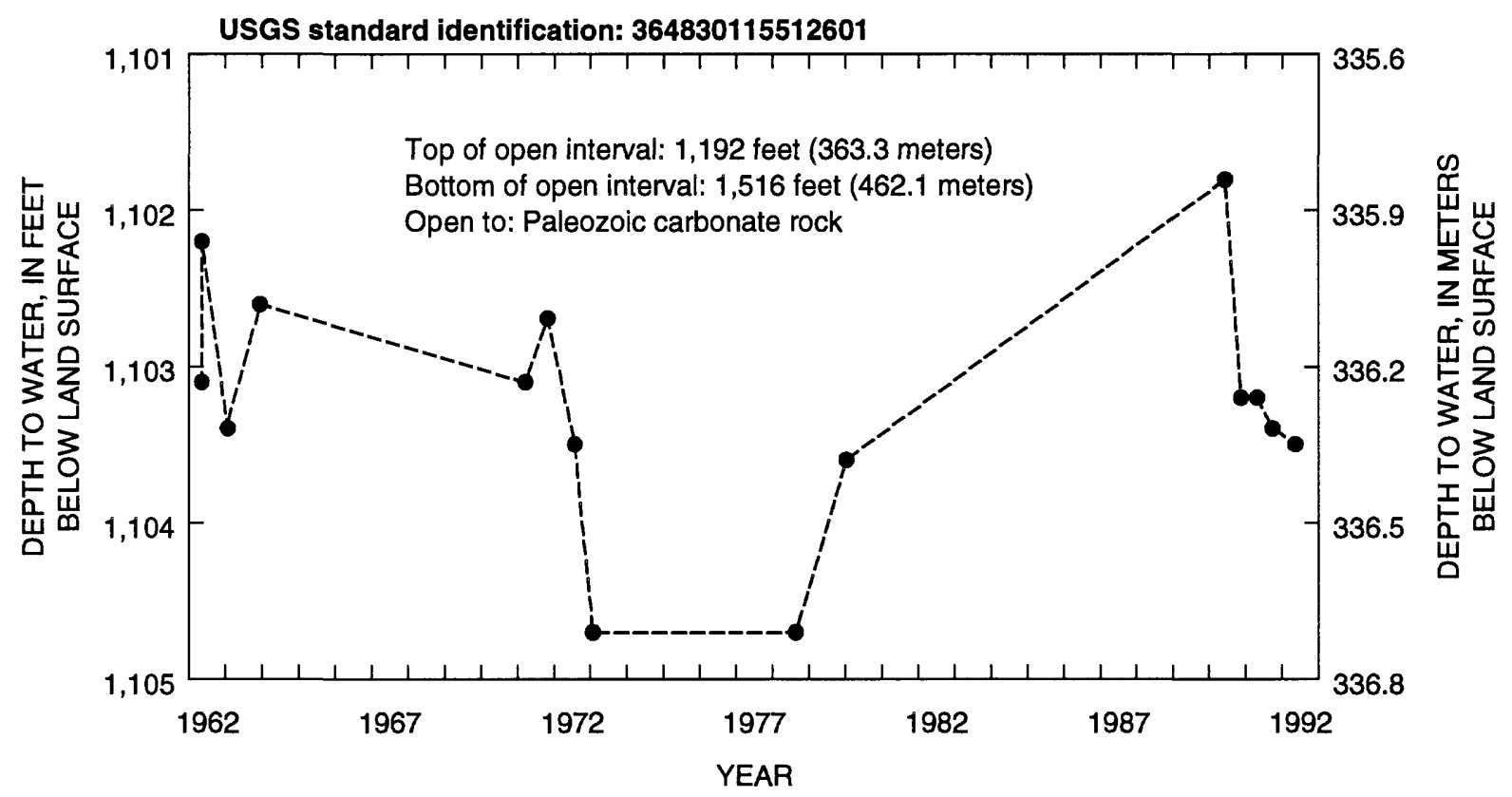

Figure 12. Depth to water through water year 1992 in Test Well 3 in Frenchman Flat hydrographic area in vicinity of Nevada Test Site.

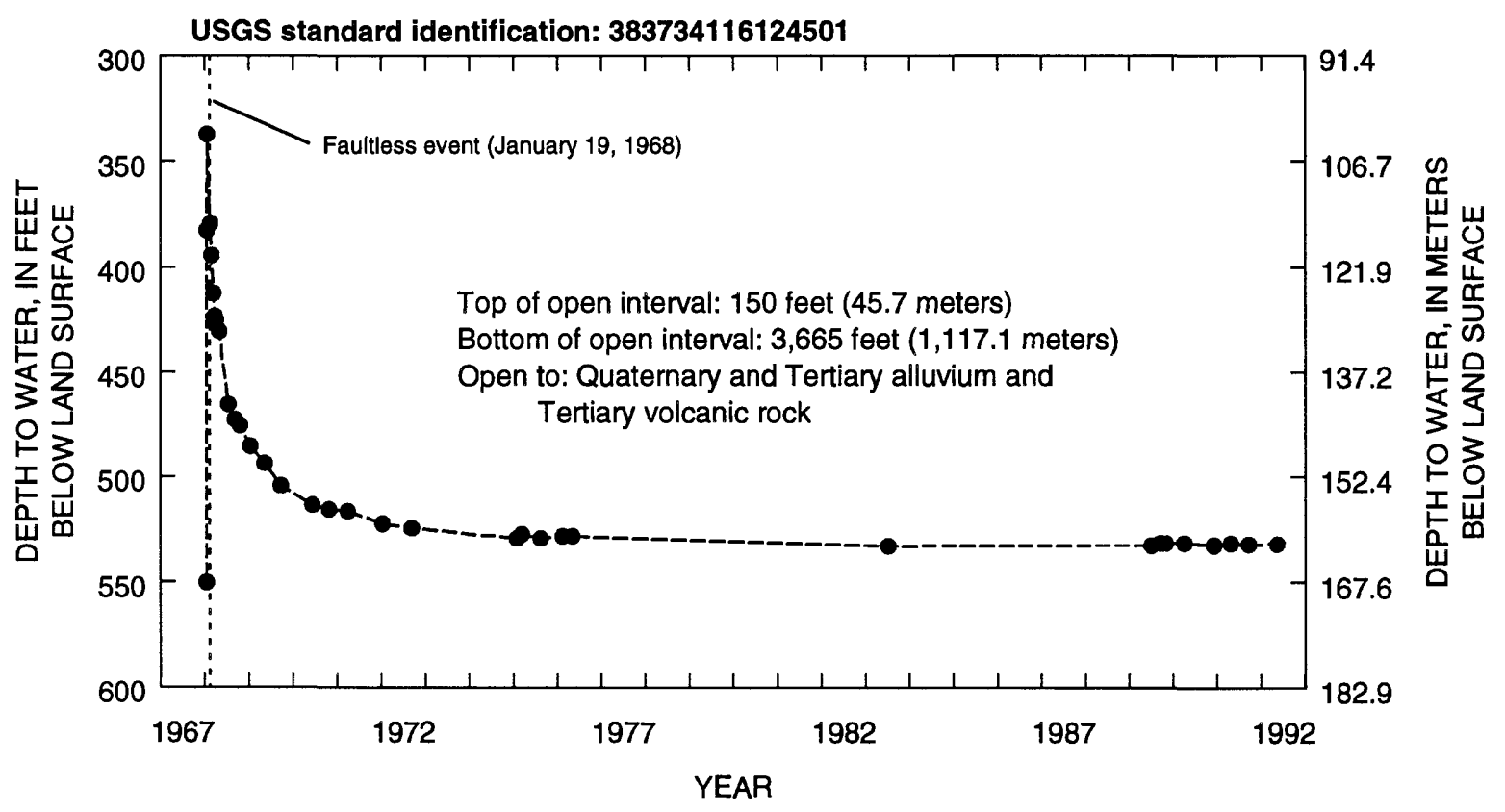

Figure 13. Depth to water through water year 1992 in test hole HTH-1 in Hot Creek Valley hydrographic area in vicinity of Nevada Test Site. Name and date are indicated for nearby nuclear test. 


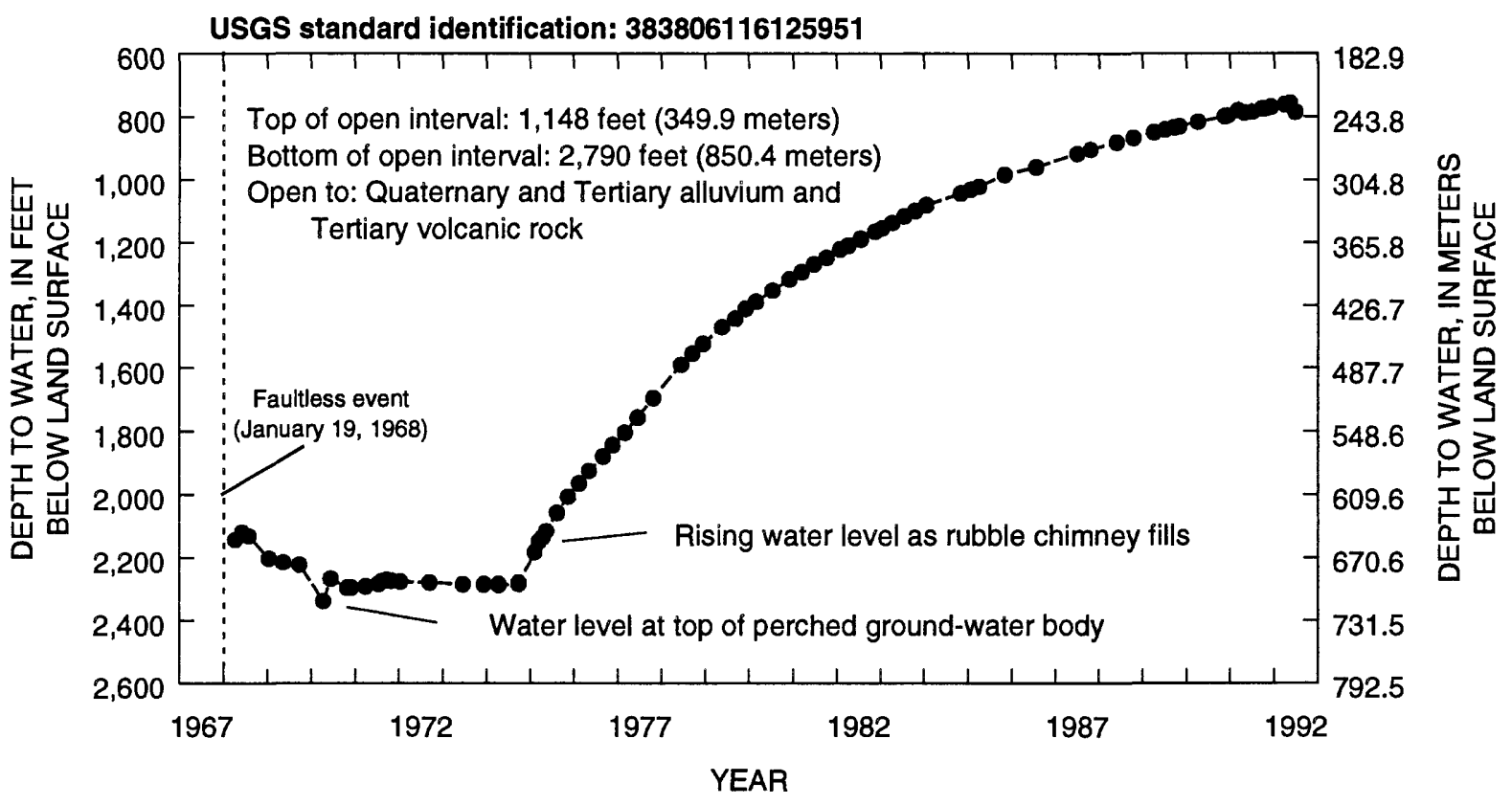

Figure 14. Depth to water through water year 1992 in test hole UC-1-P-2SR in Hot Creek Valley hydrographic area in vicinity of Nevada Test Site. Name and date are indicated for nearby nuclear test.

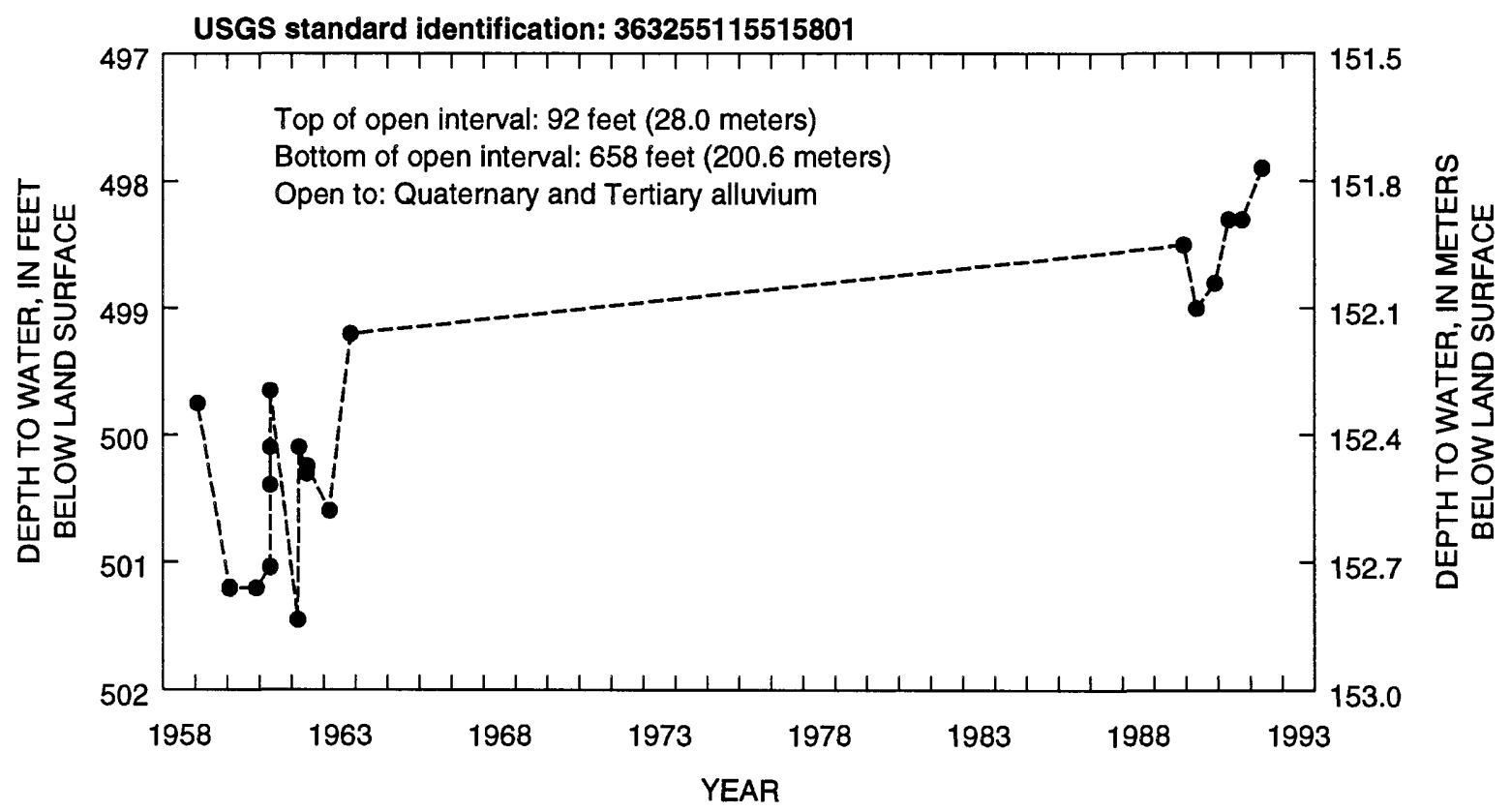

Figure 15. Depth to water through water year 1992 in well Army 2 in Indian Springs Valley hydrographic area in vicinity of Nevada Test Site. 


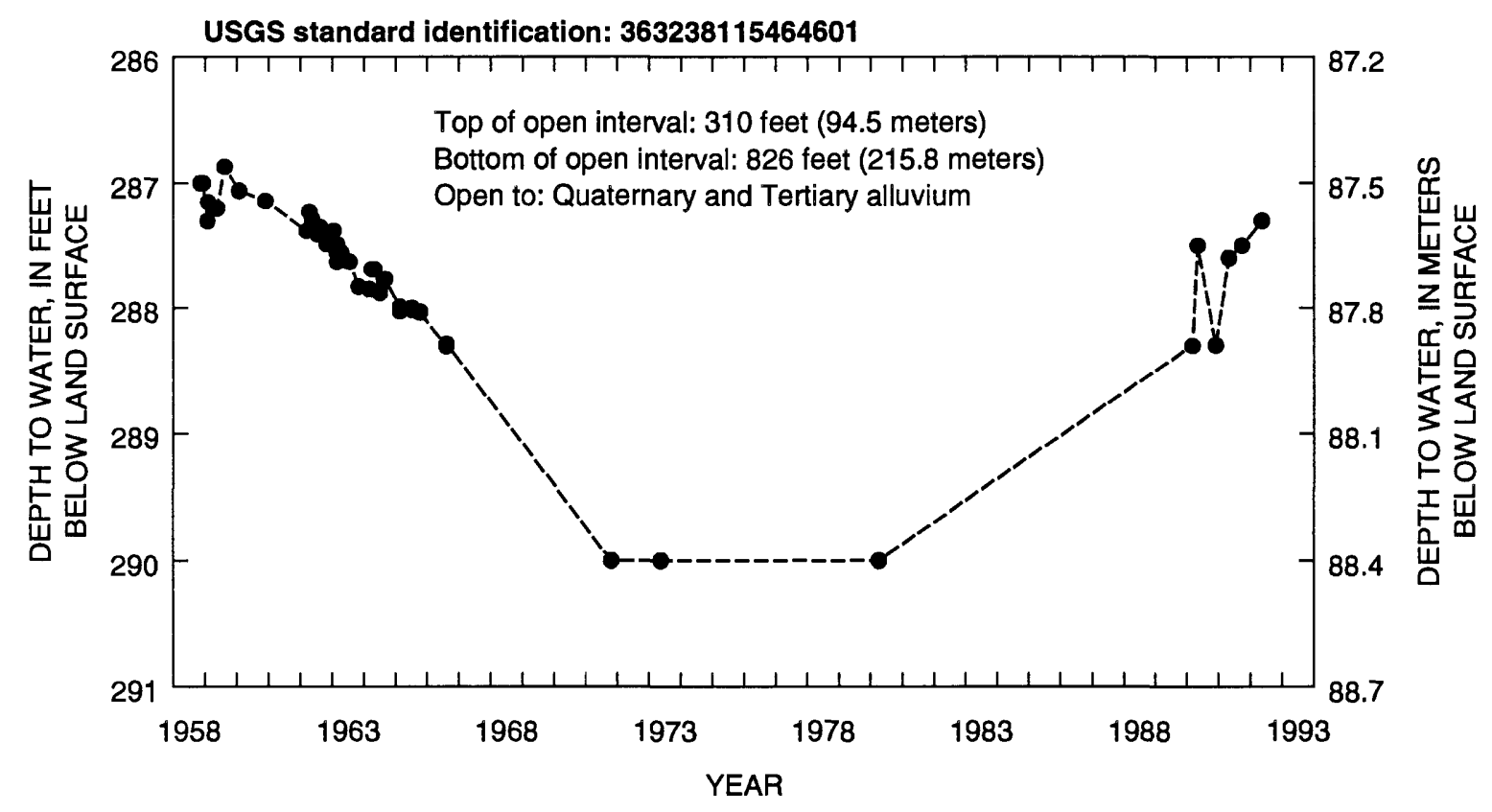

Figure 16. Depth to water through water year 1992 in well Army 3 in Indian Springs Valley hydrographic area in vicinity of Nevada Test Site.

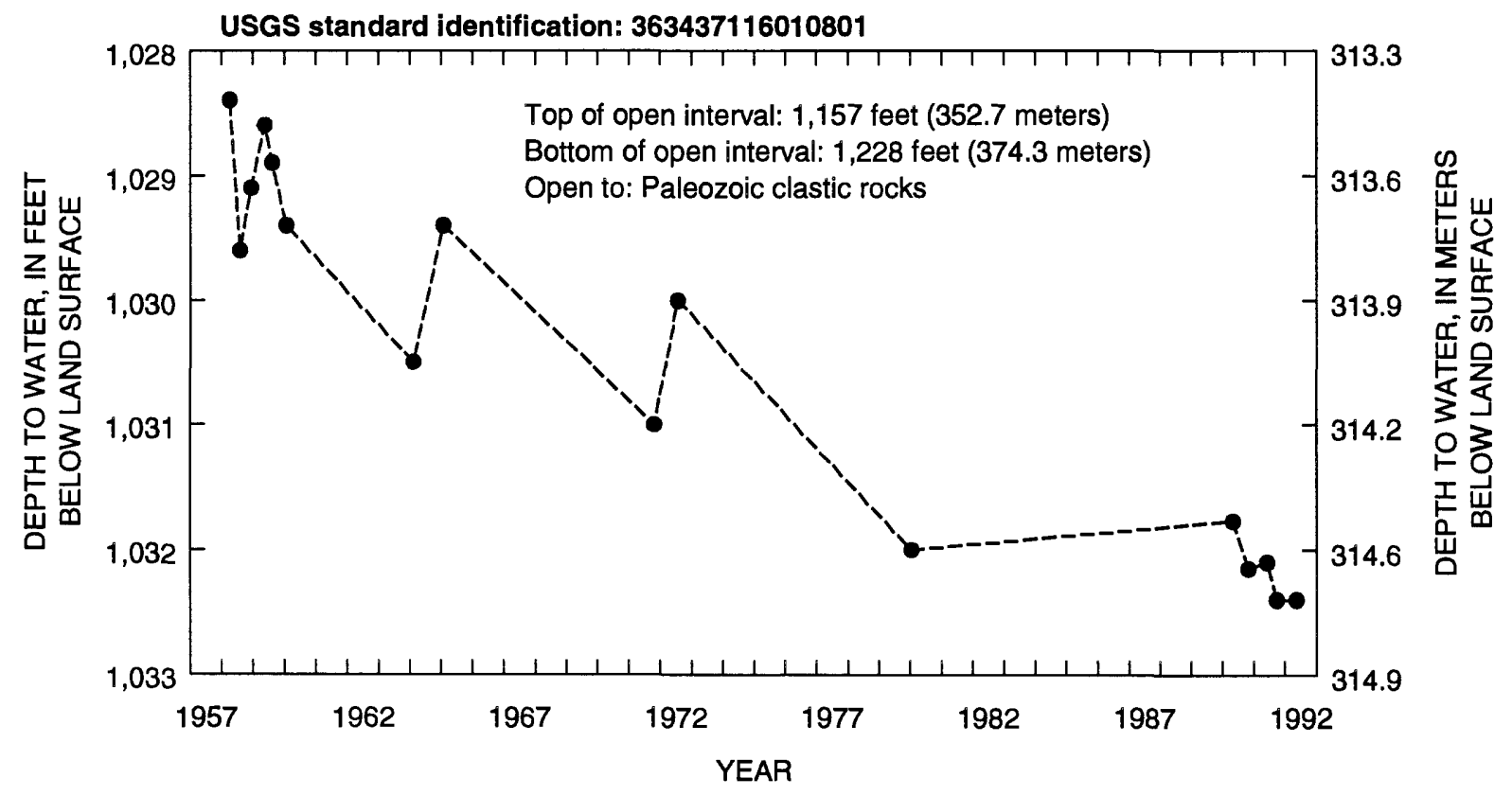

Figure 17. Depth to water through water year 1992 in well Army 6A in Mercury Valley hydrographic area in vicinity of Nevada Test Site. 


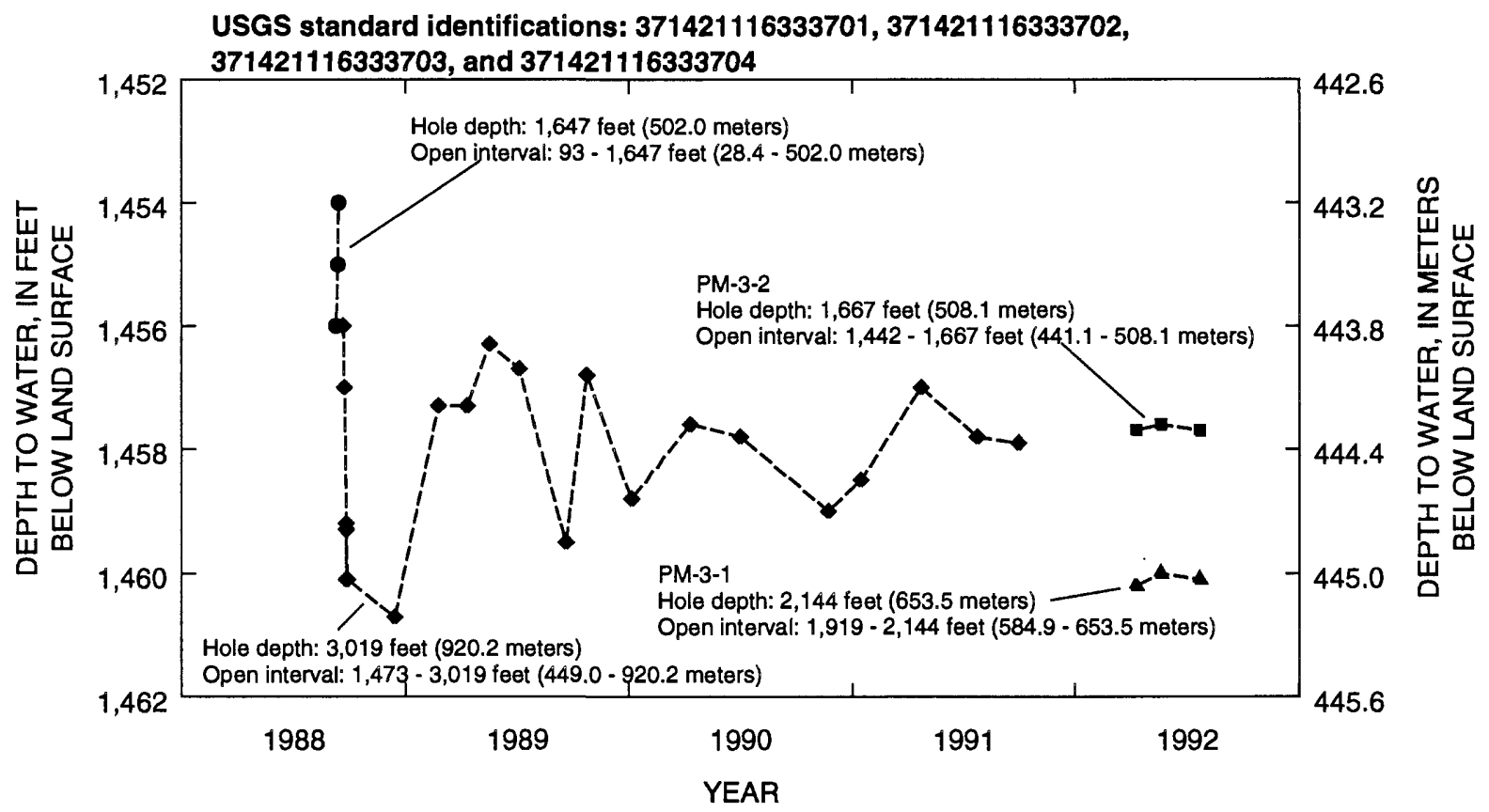

Figure 18. Depth to water through water year 1992 in test hole PM-3 in Oasis Valley hydrographic area in vicinity of Nevada Test Site.

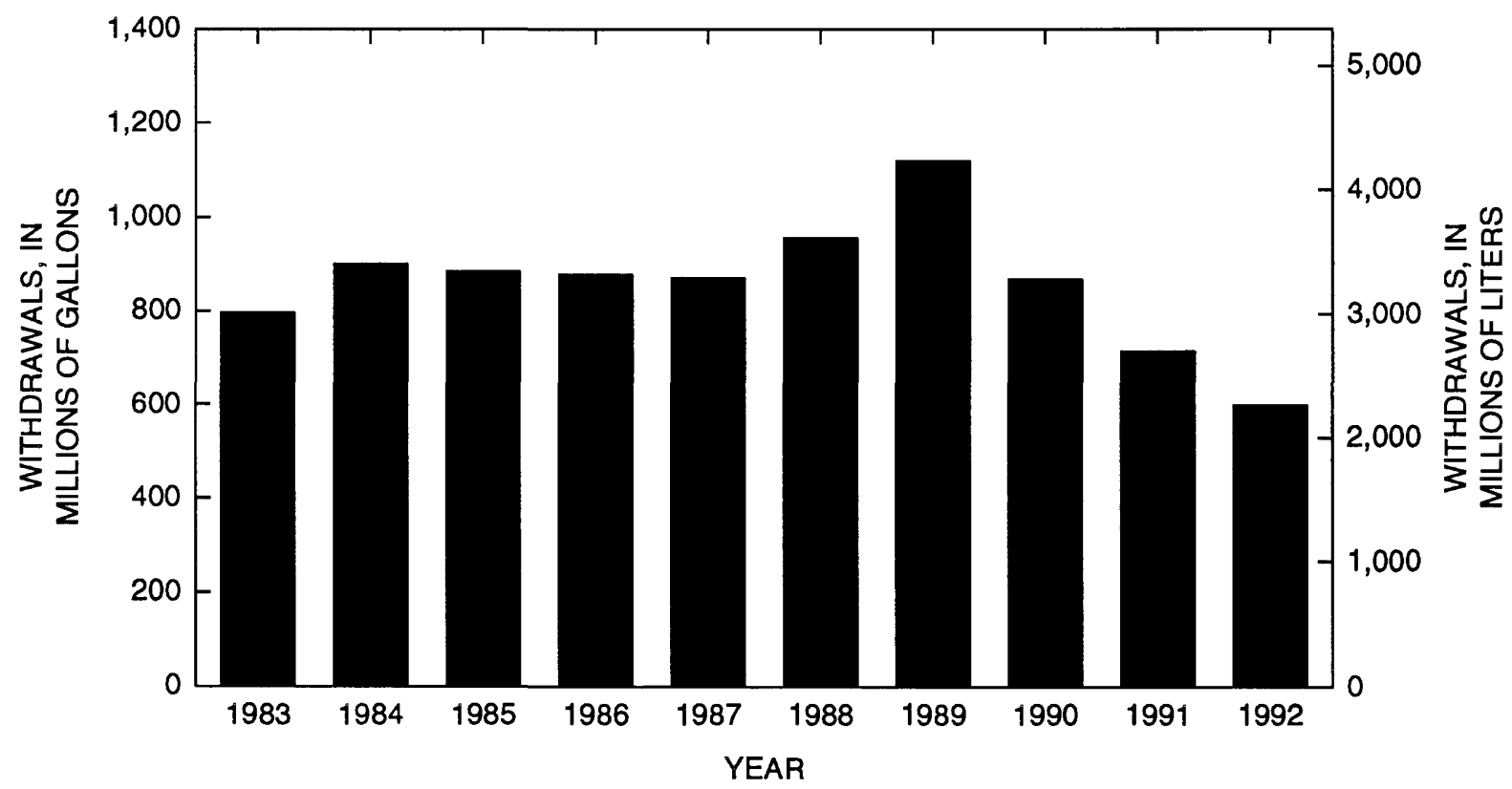

Figure 19. Annual ground-water withdrawals from Nevada Test Site, 1983-92. 


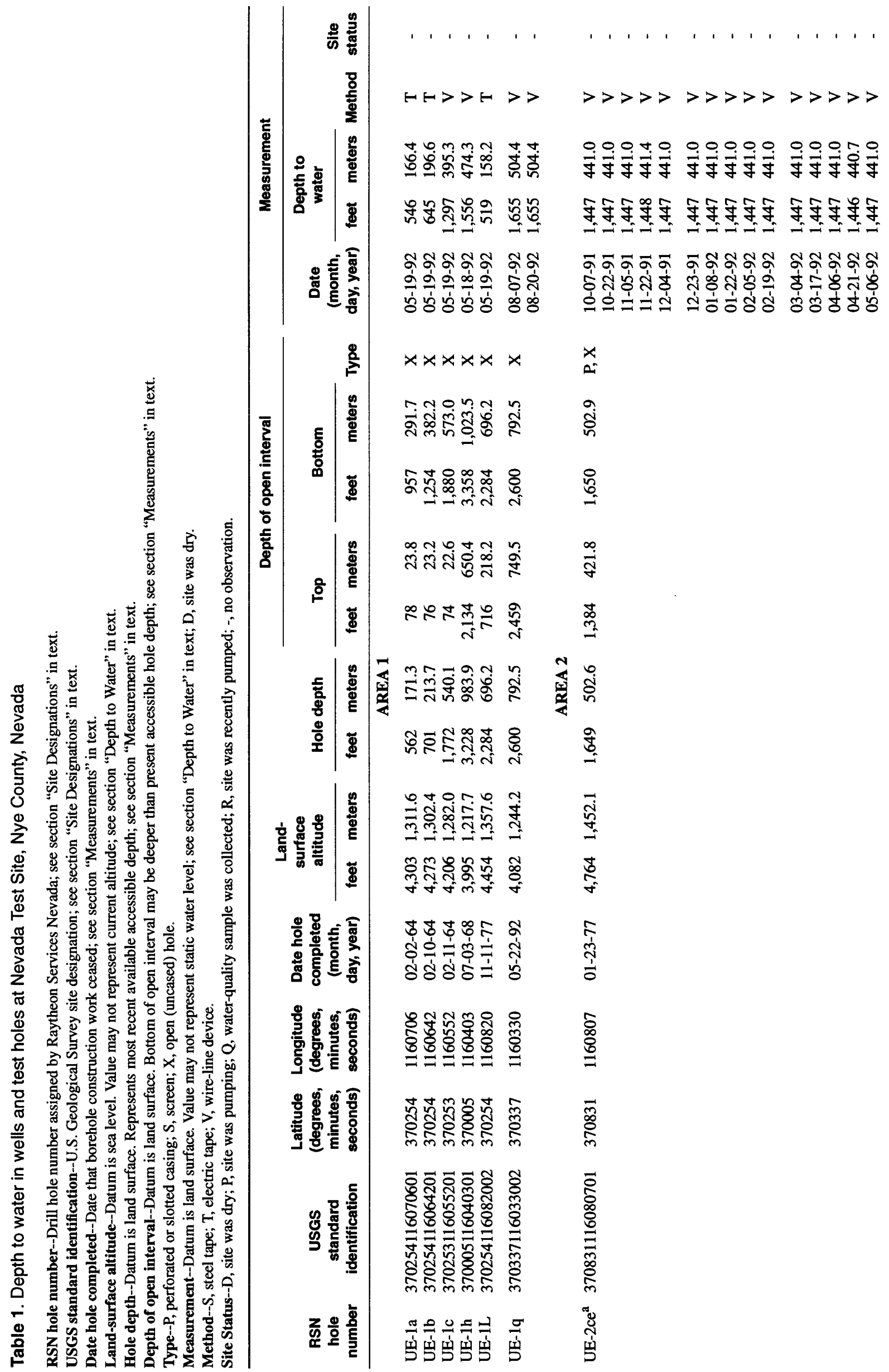




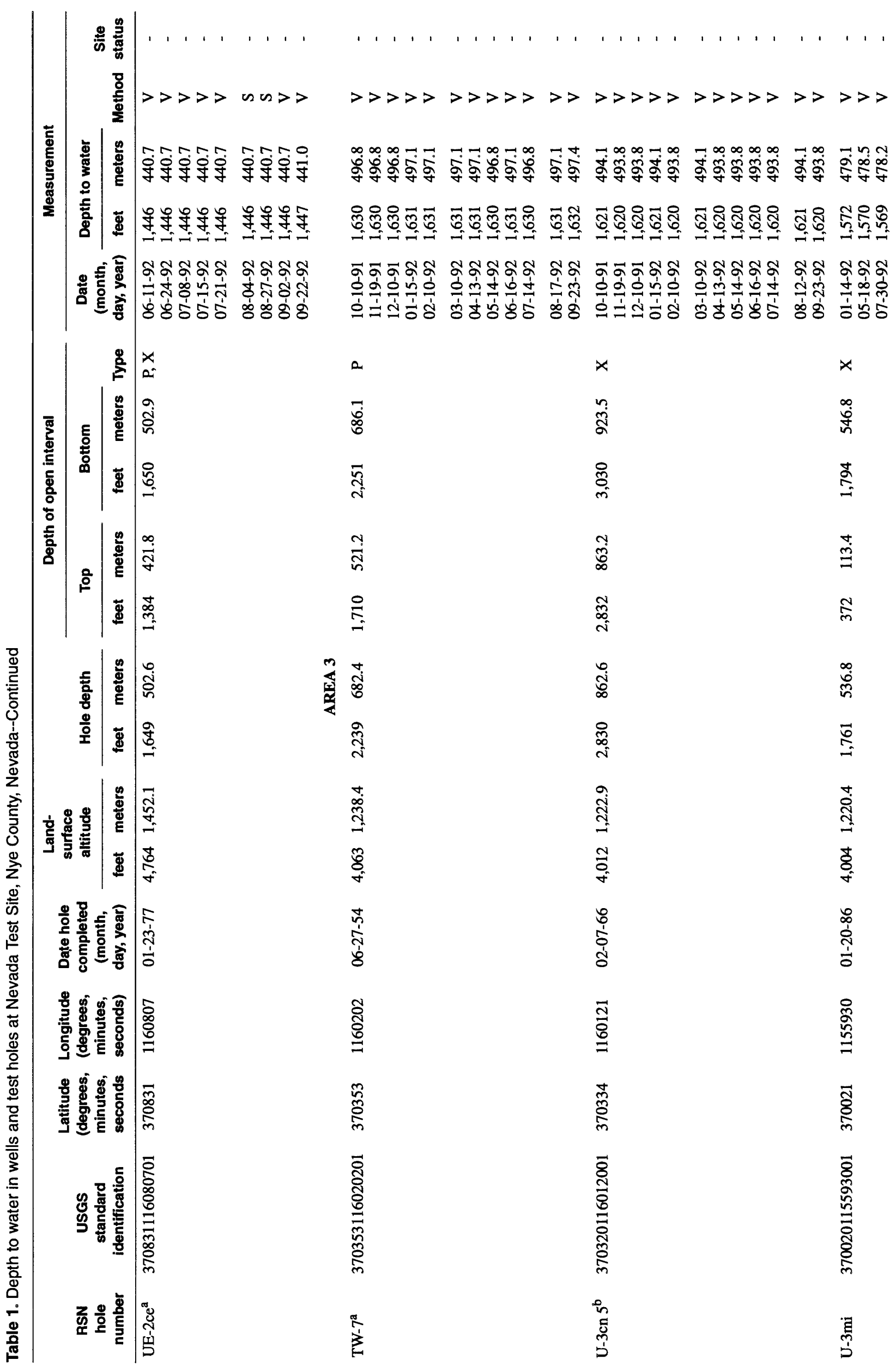




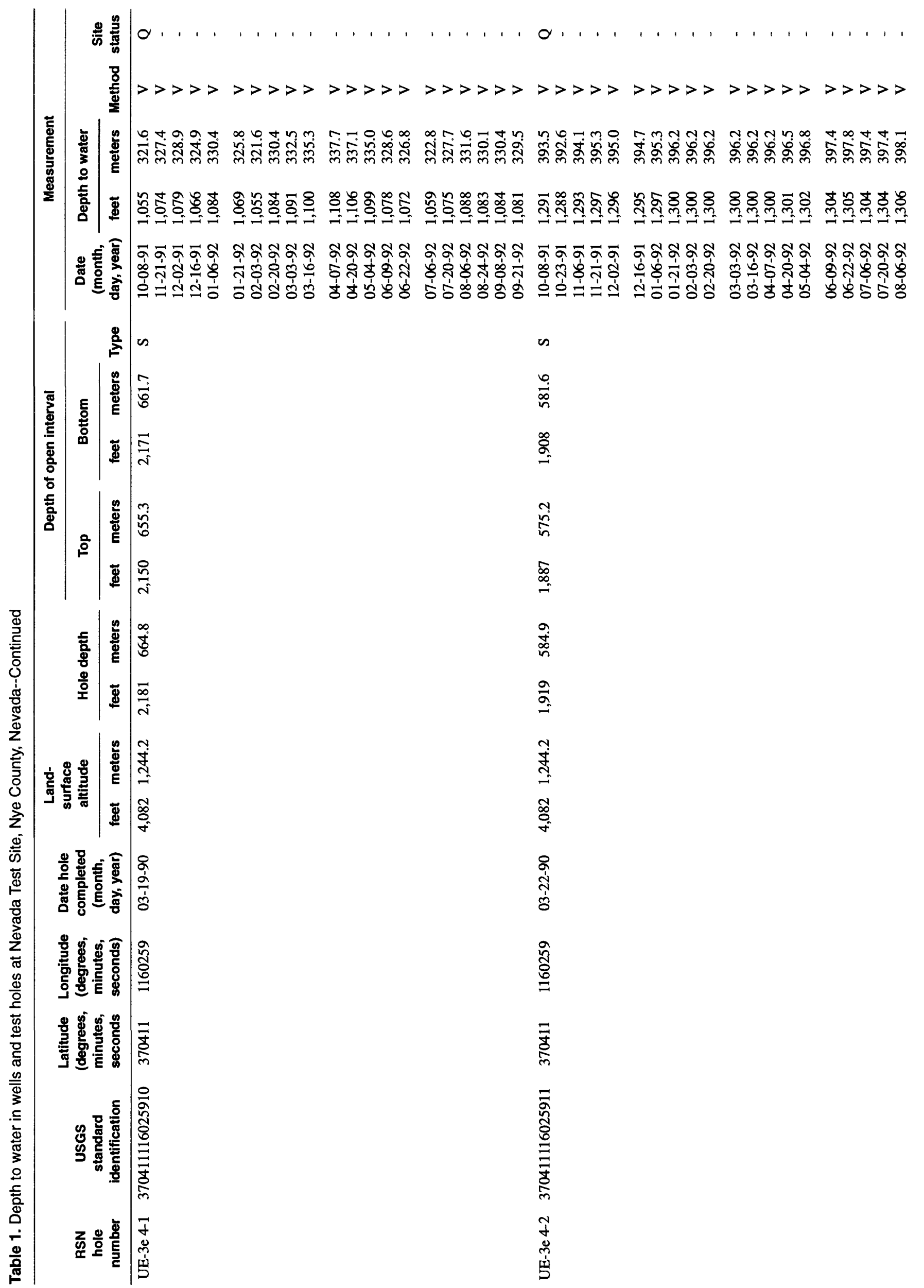




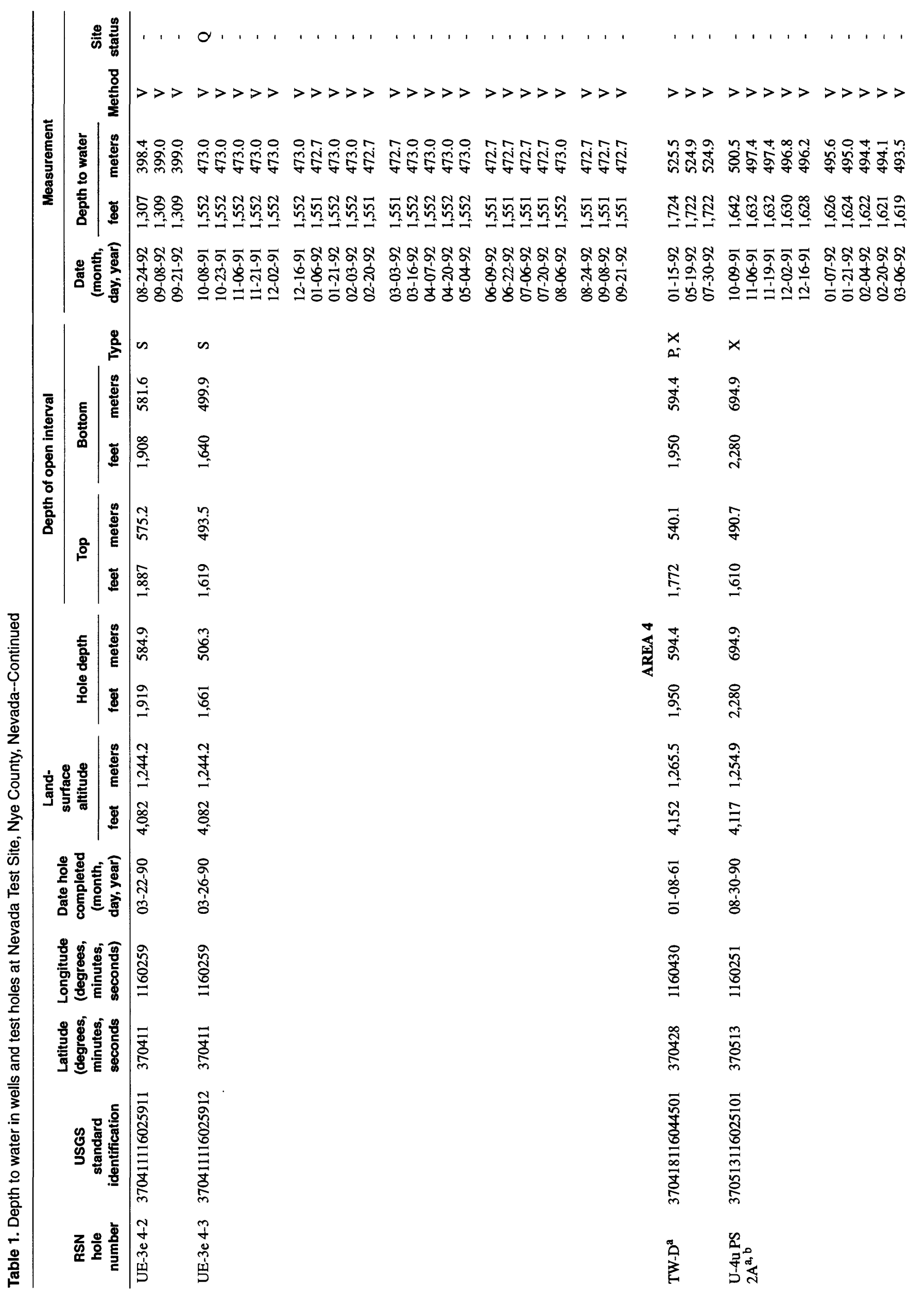




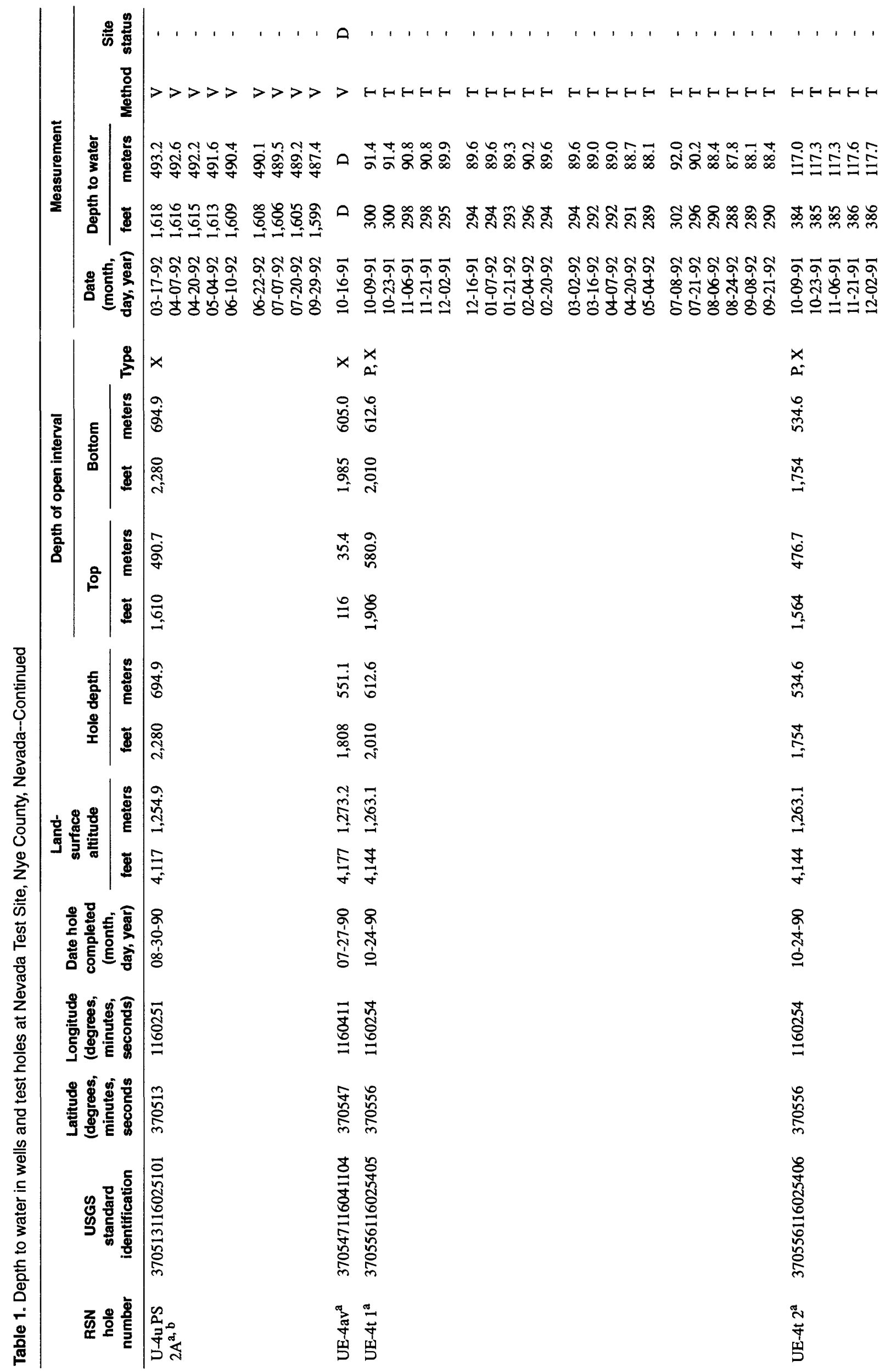




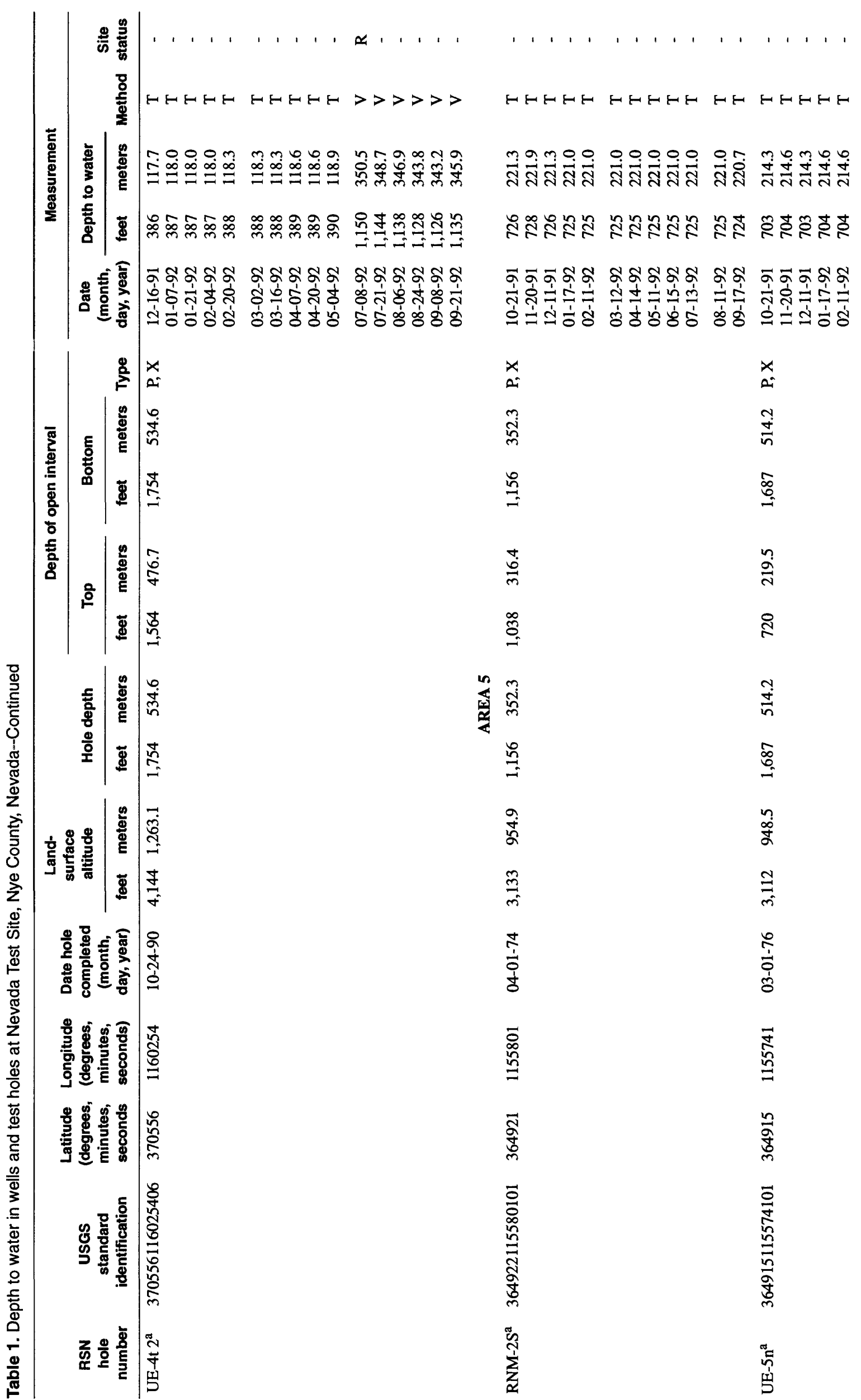




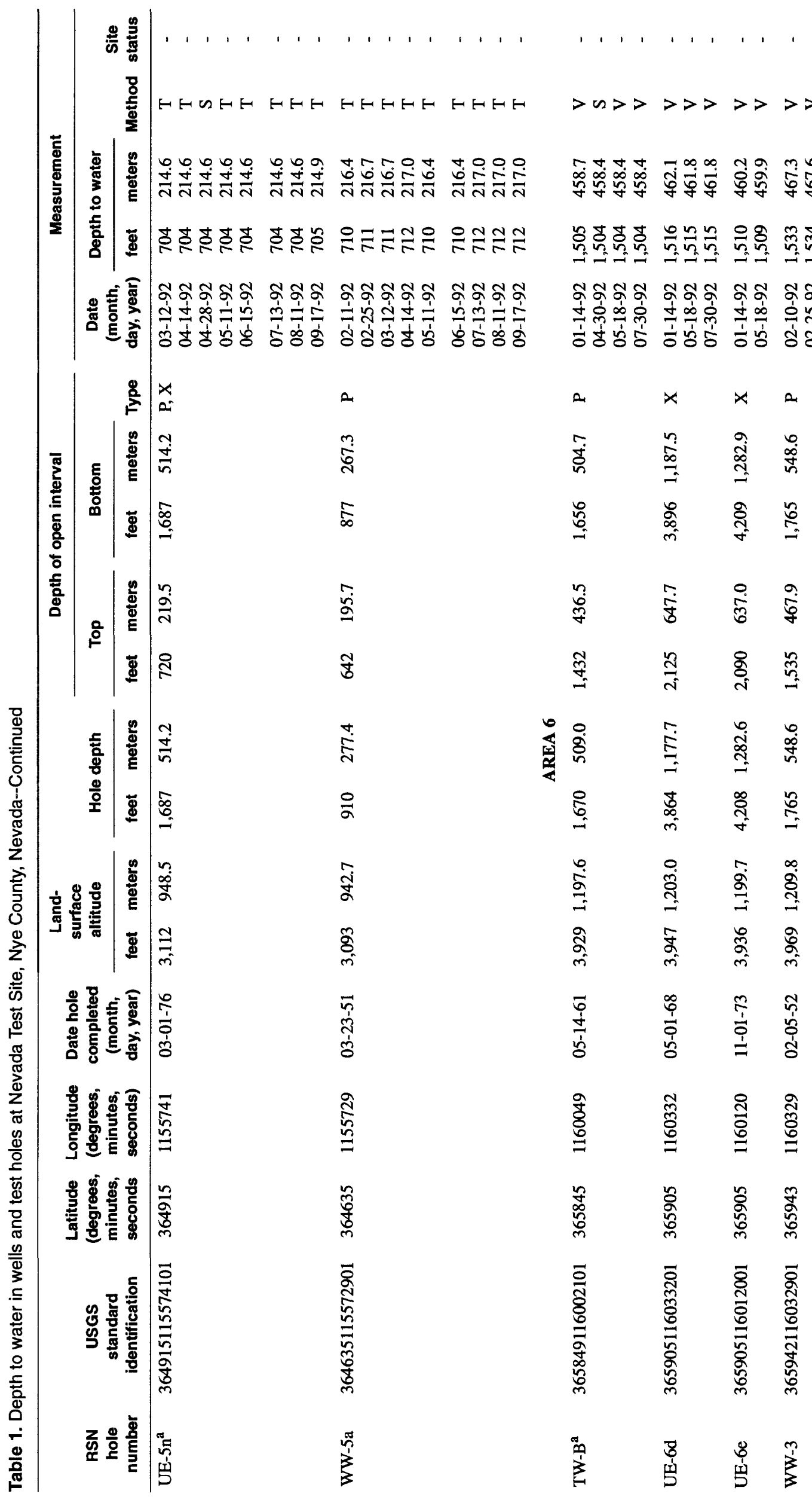




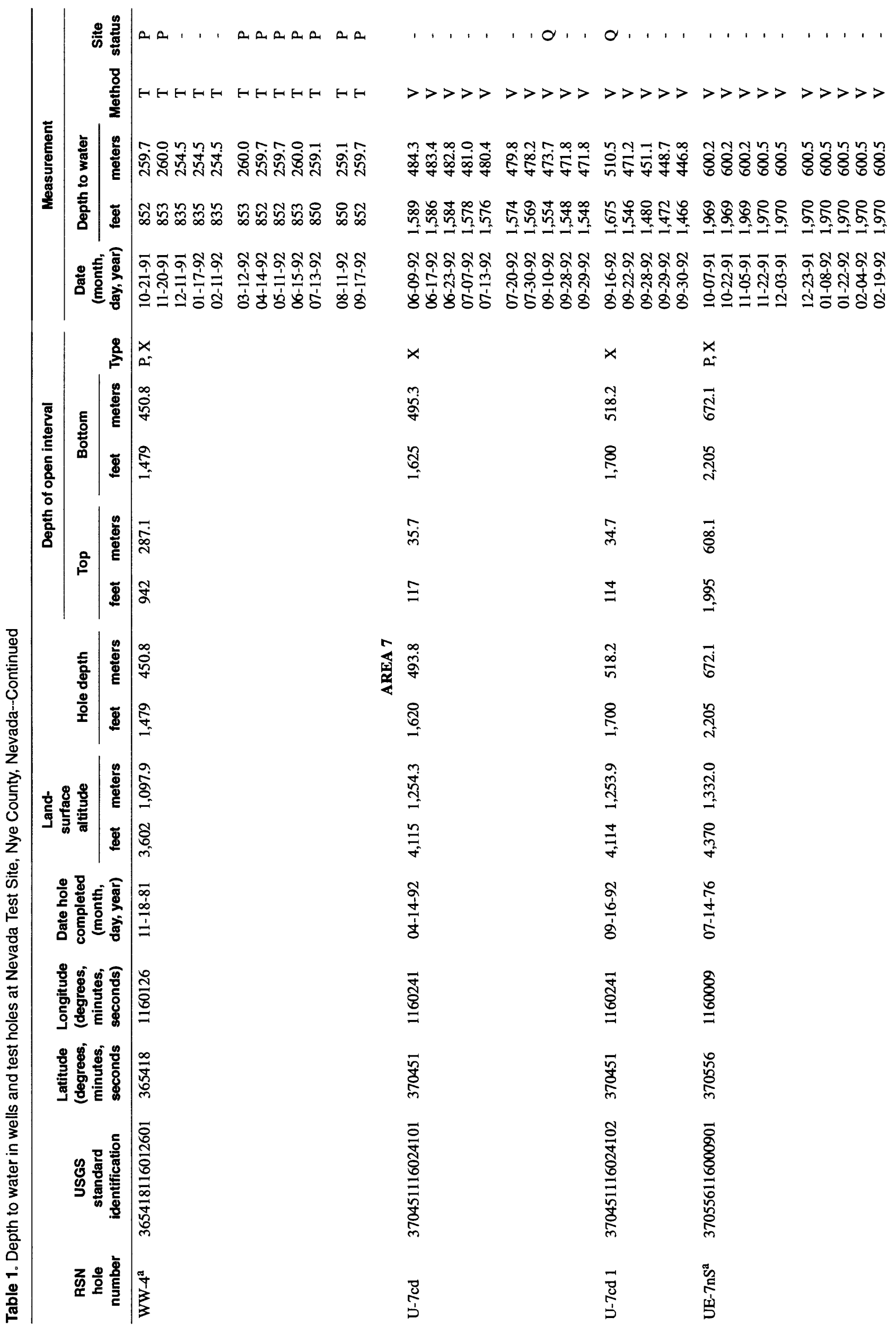




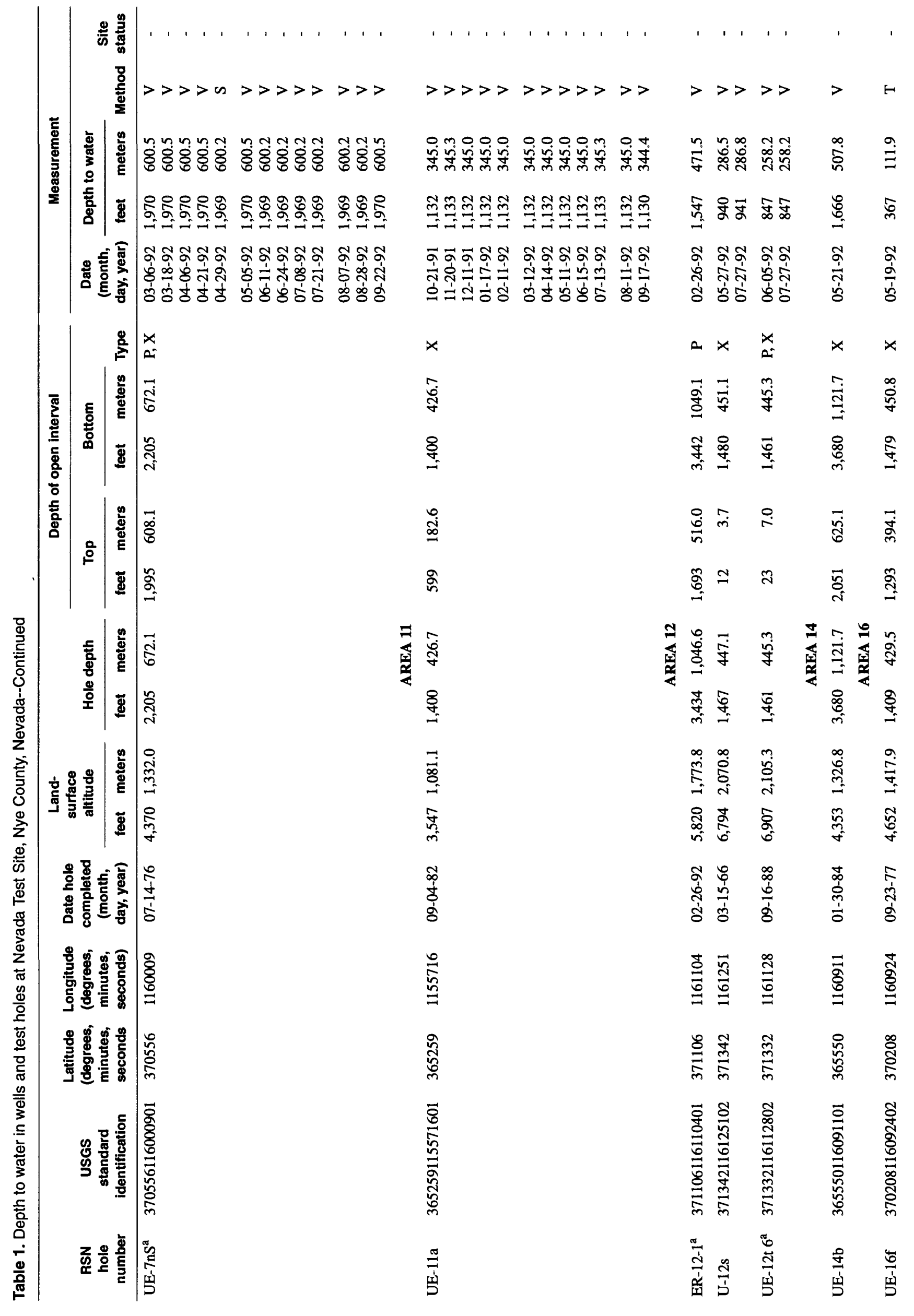




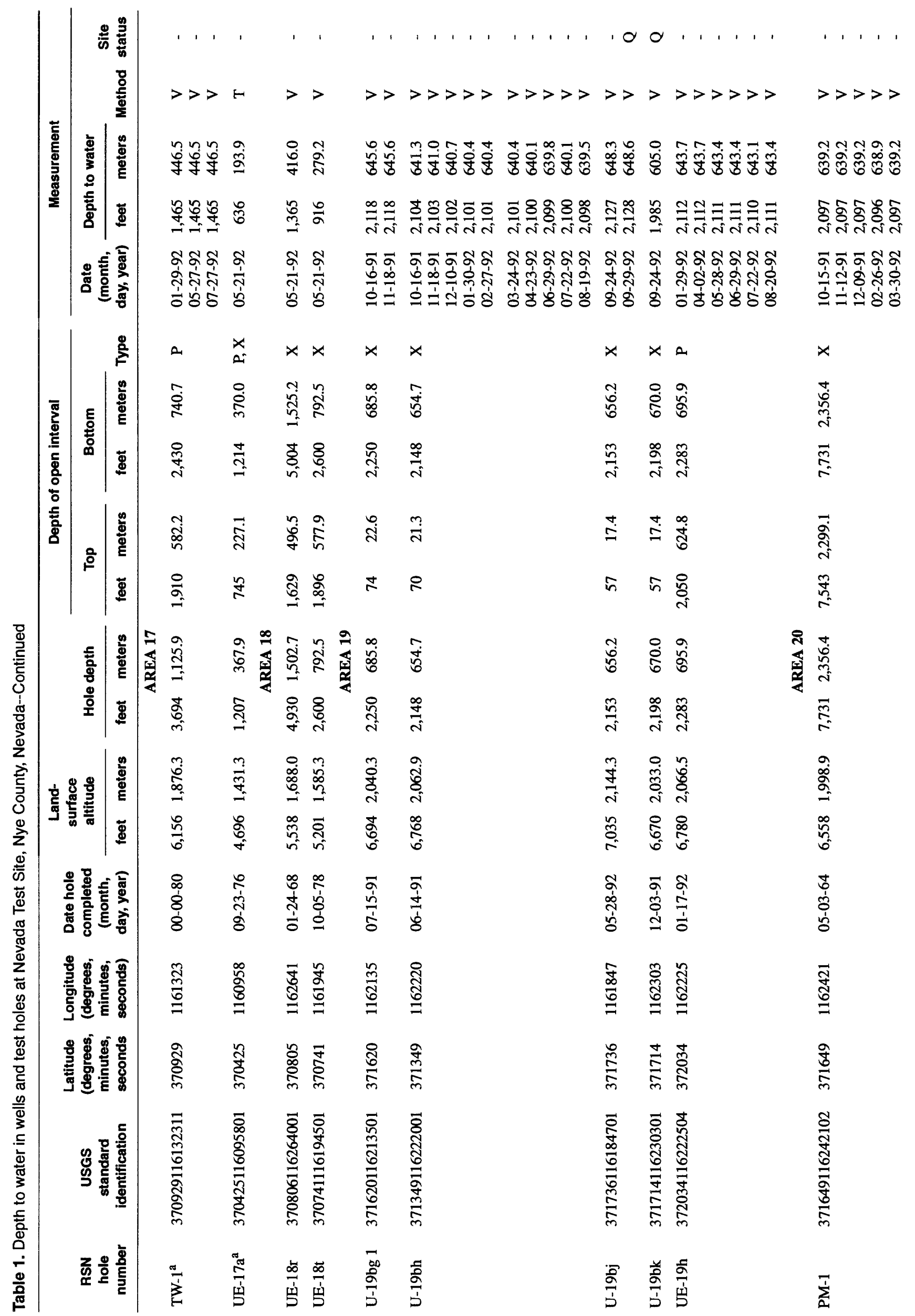




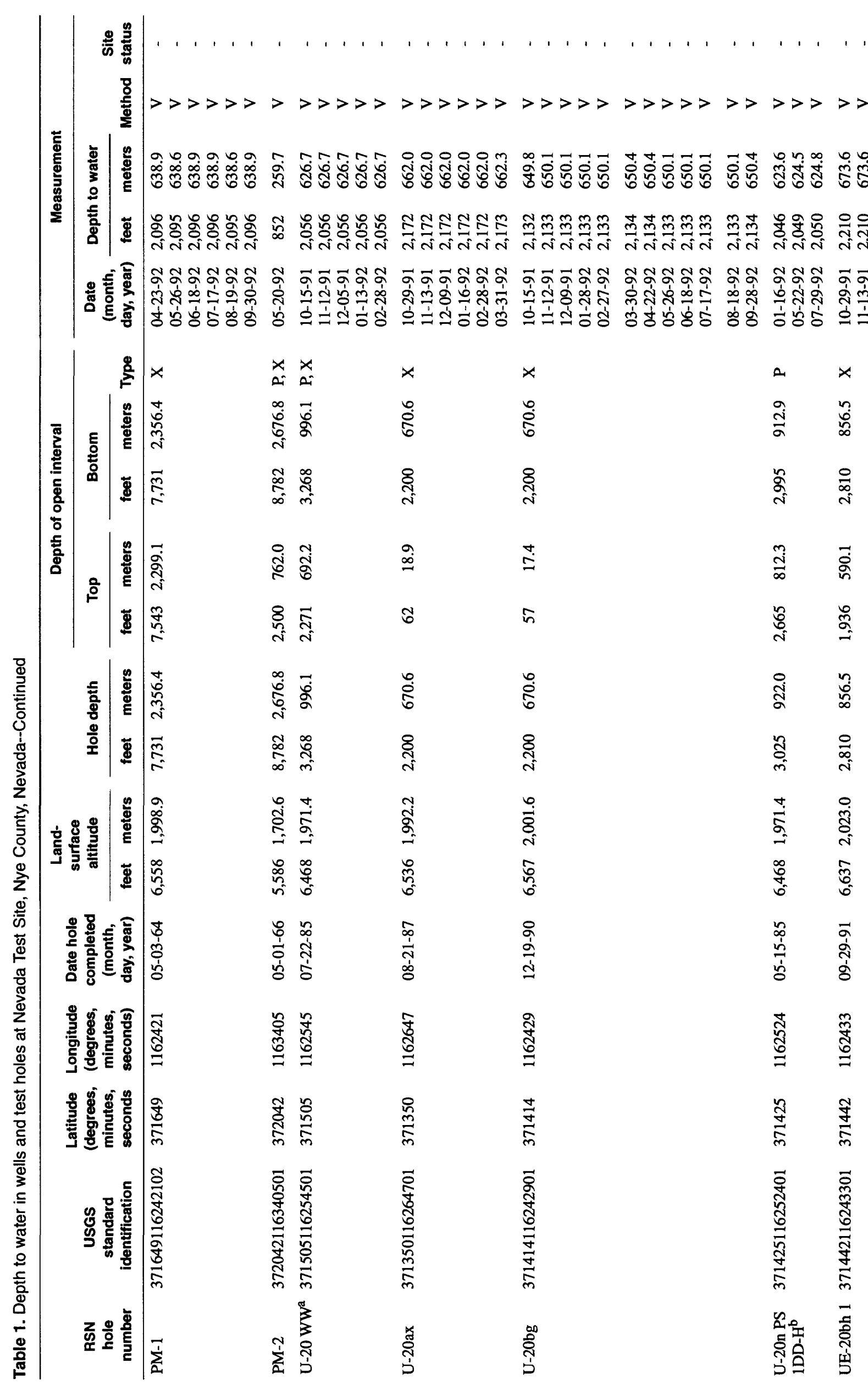




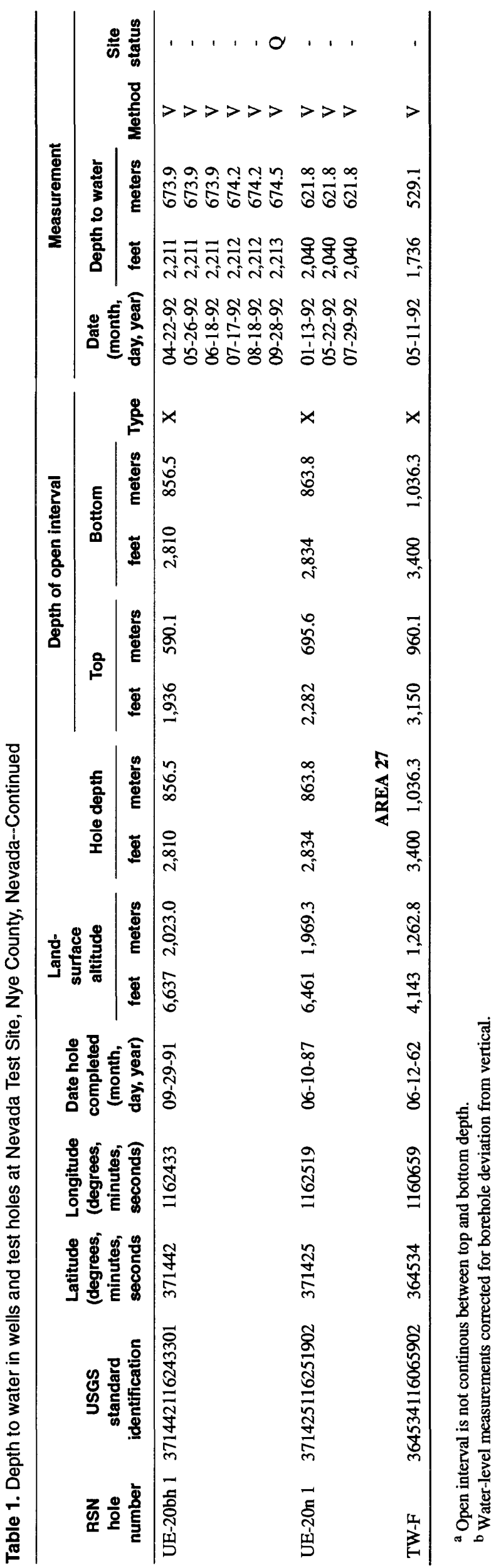

32 Ground-Water Data For the Nevada Test Site, 1992, and for Selected Other Areas in South-Central Nevada, $1952-92$ 


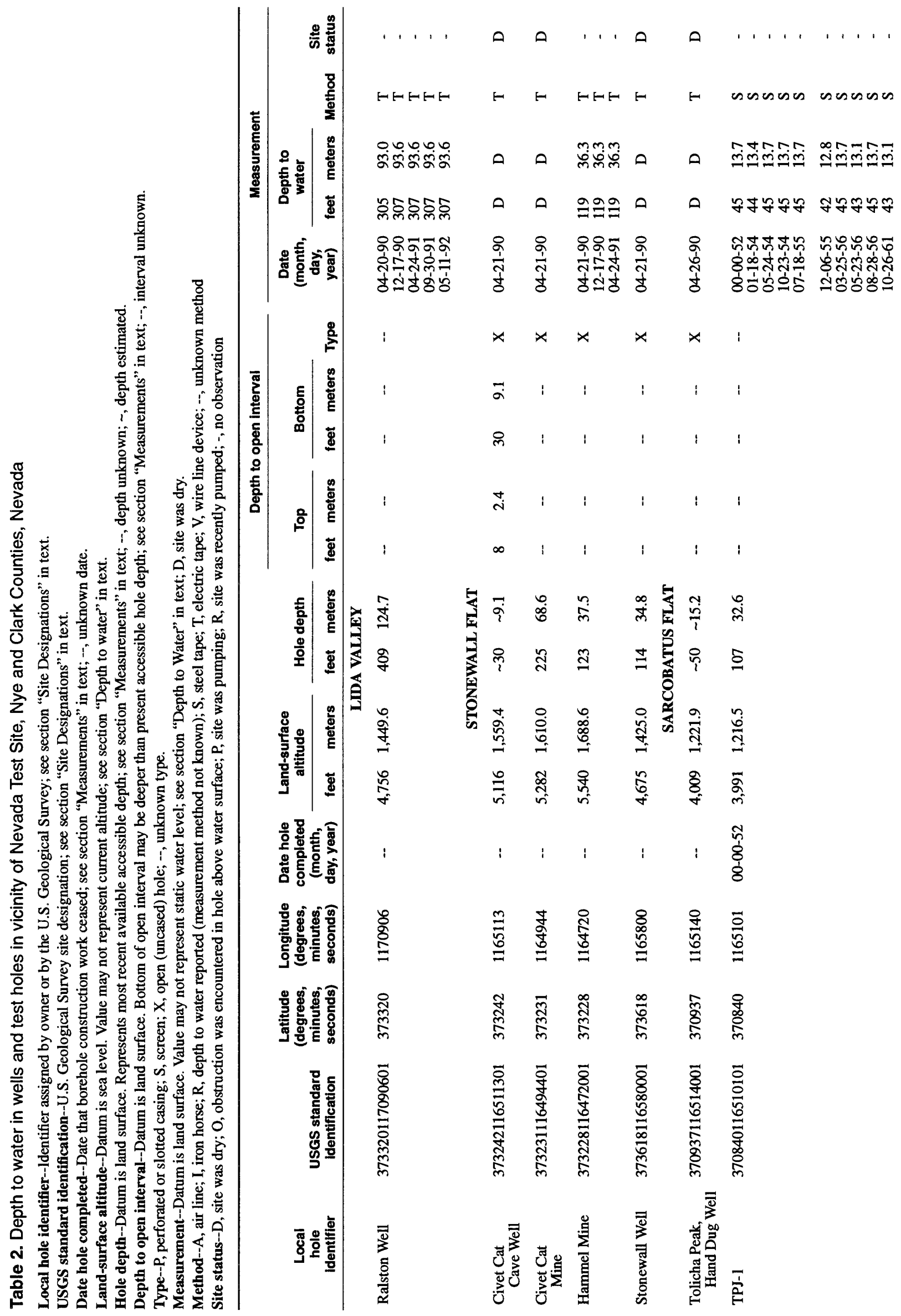




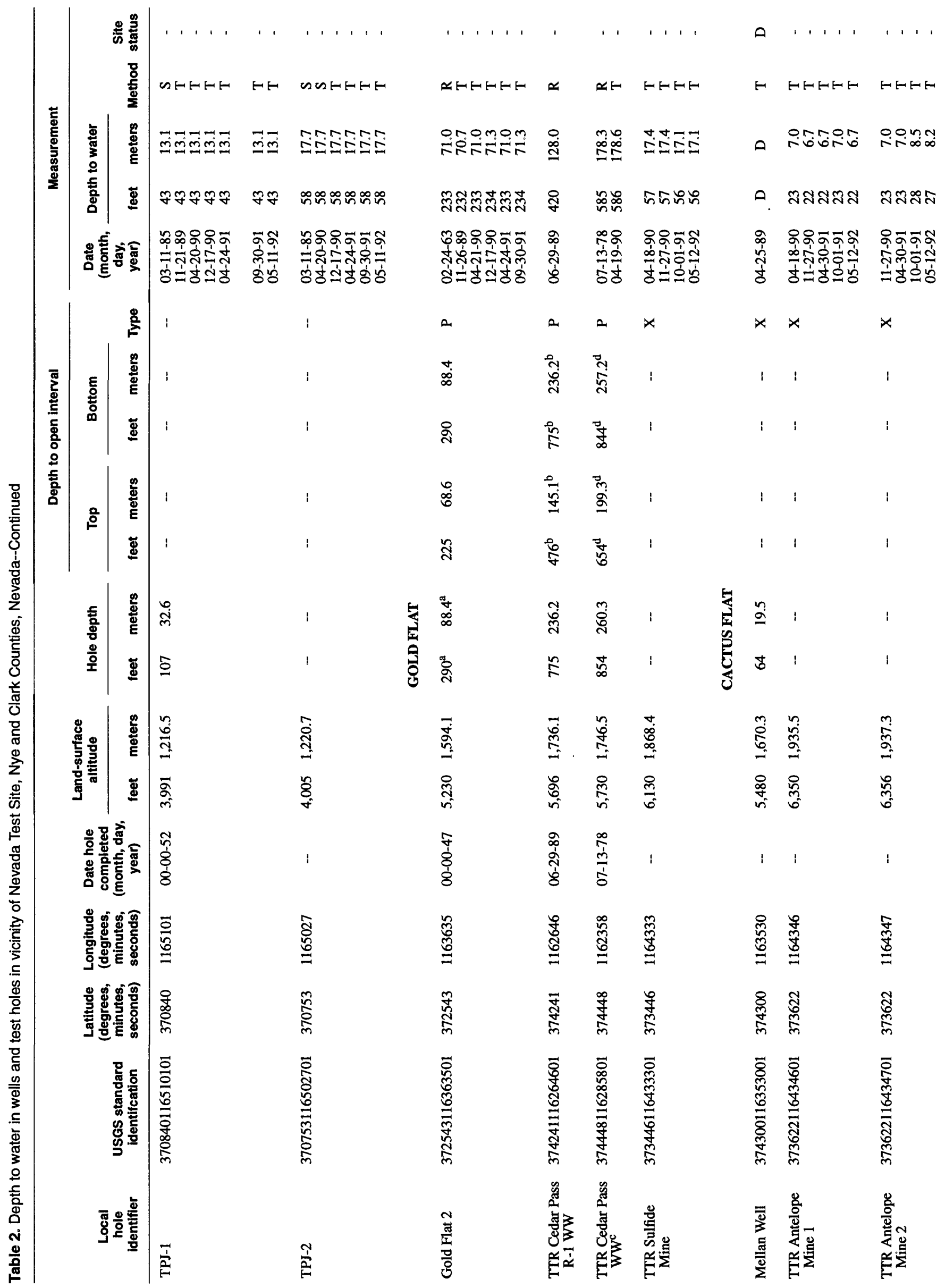




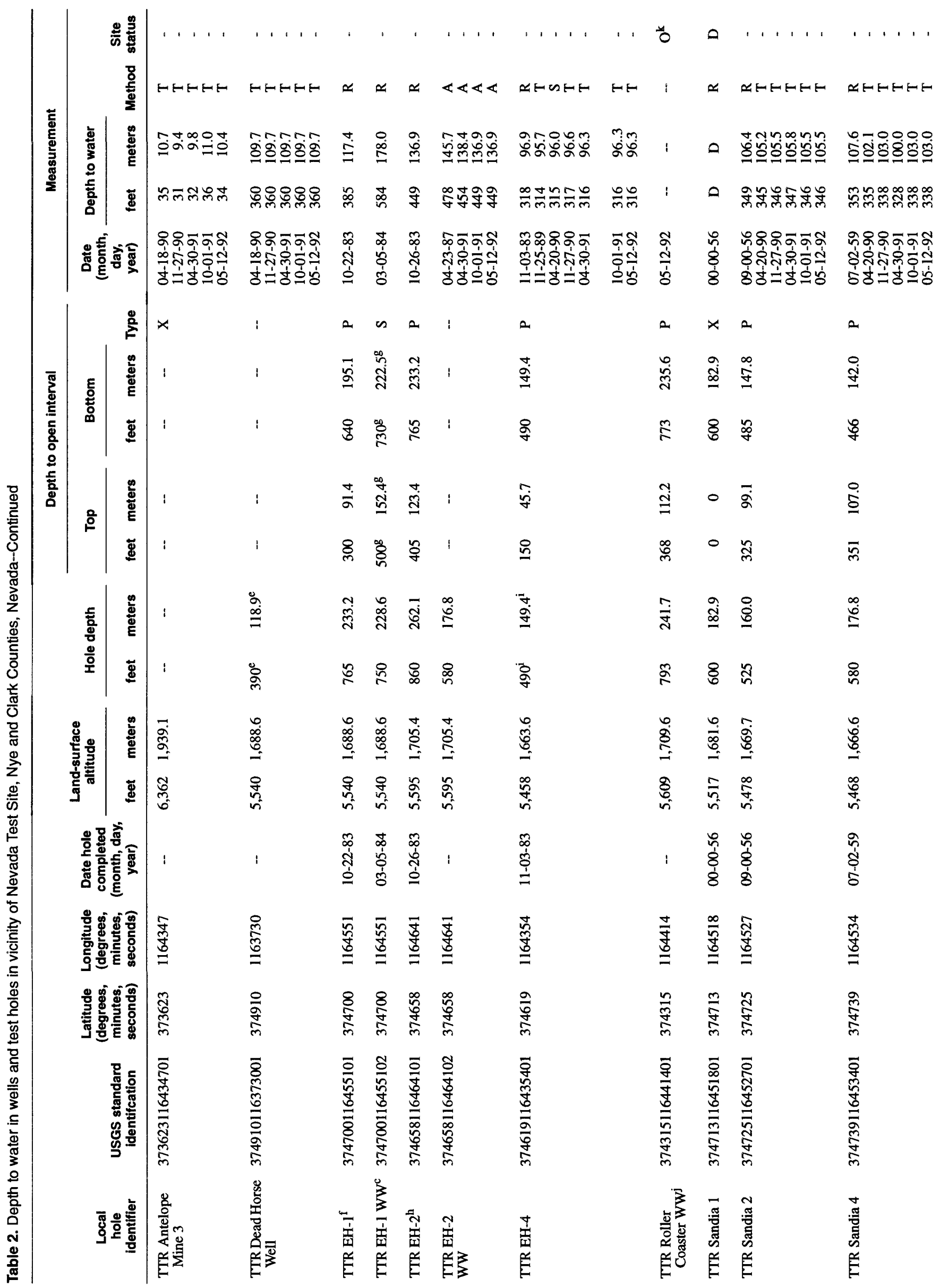




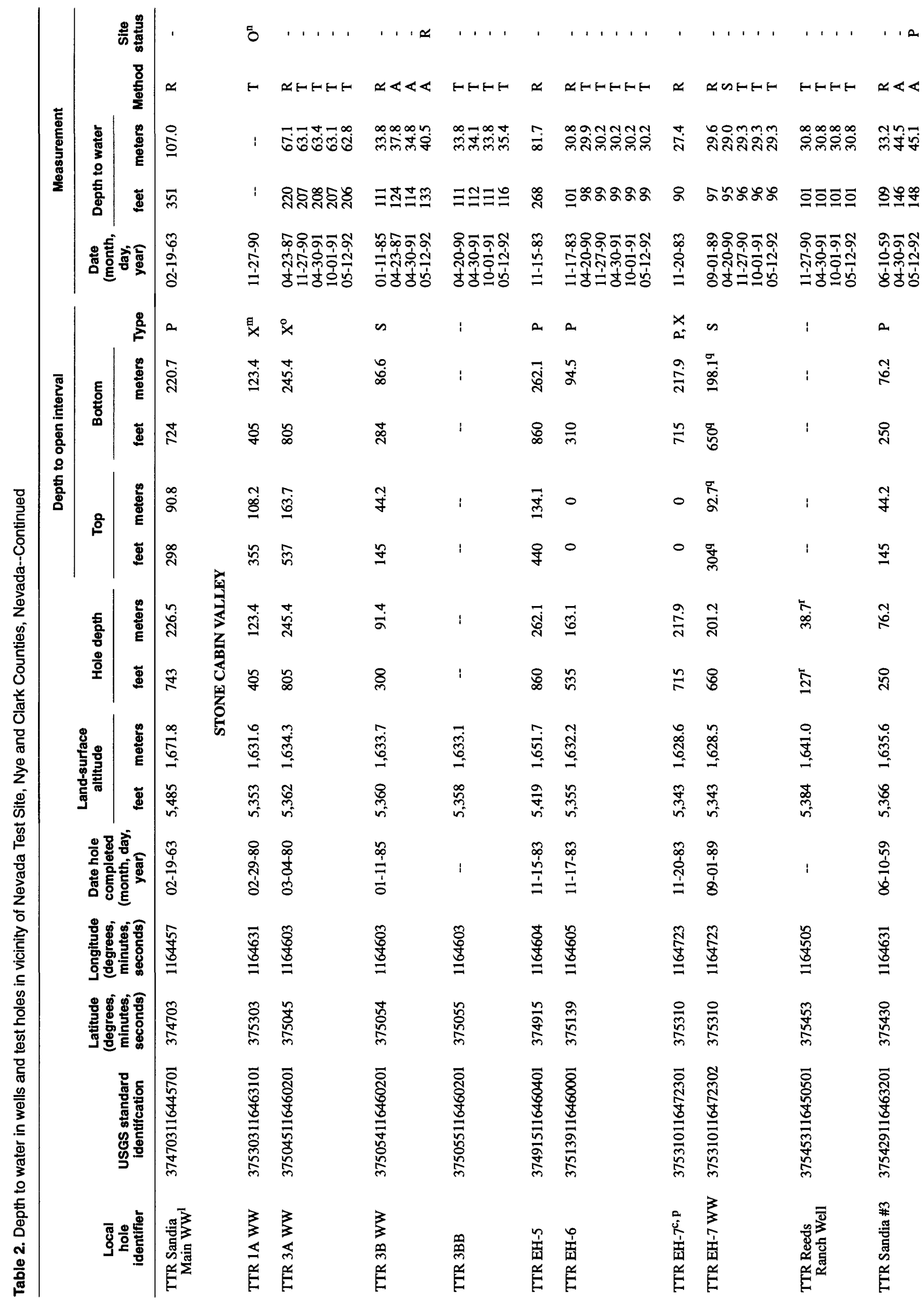




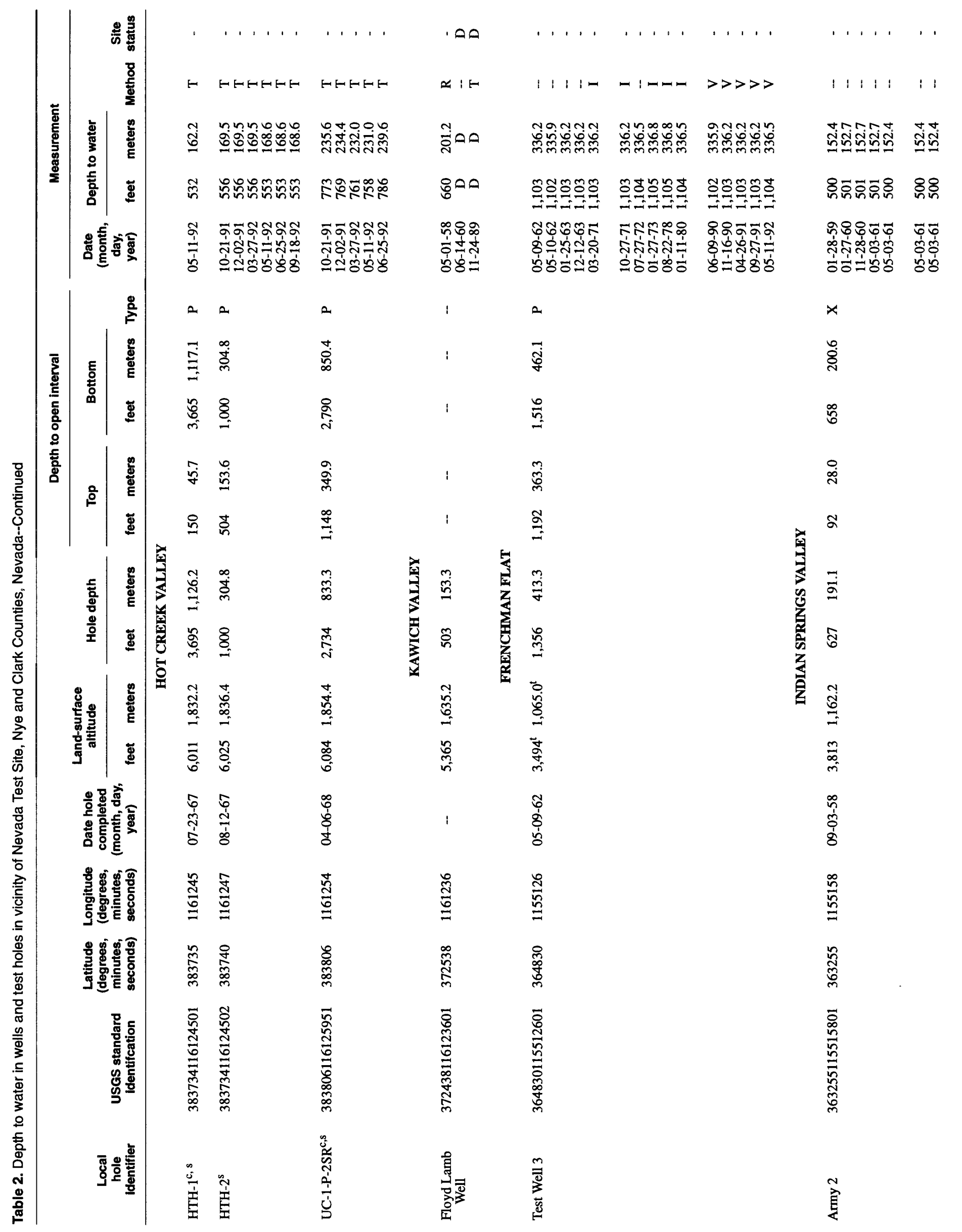




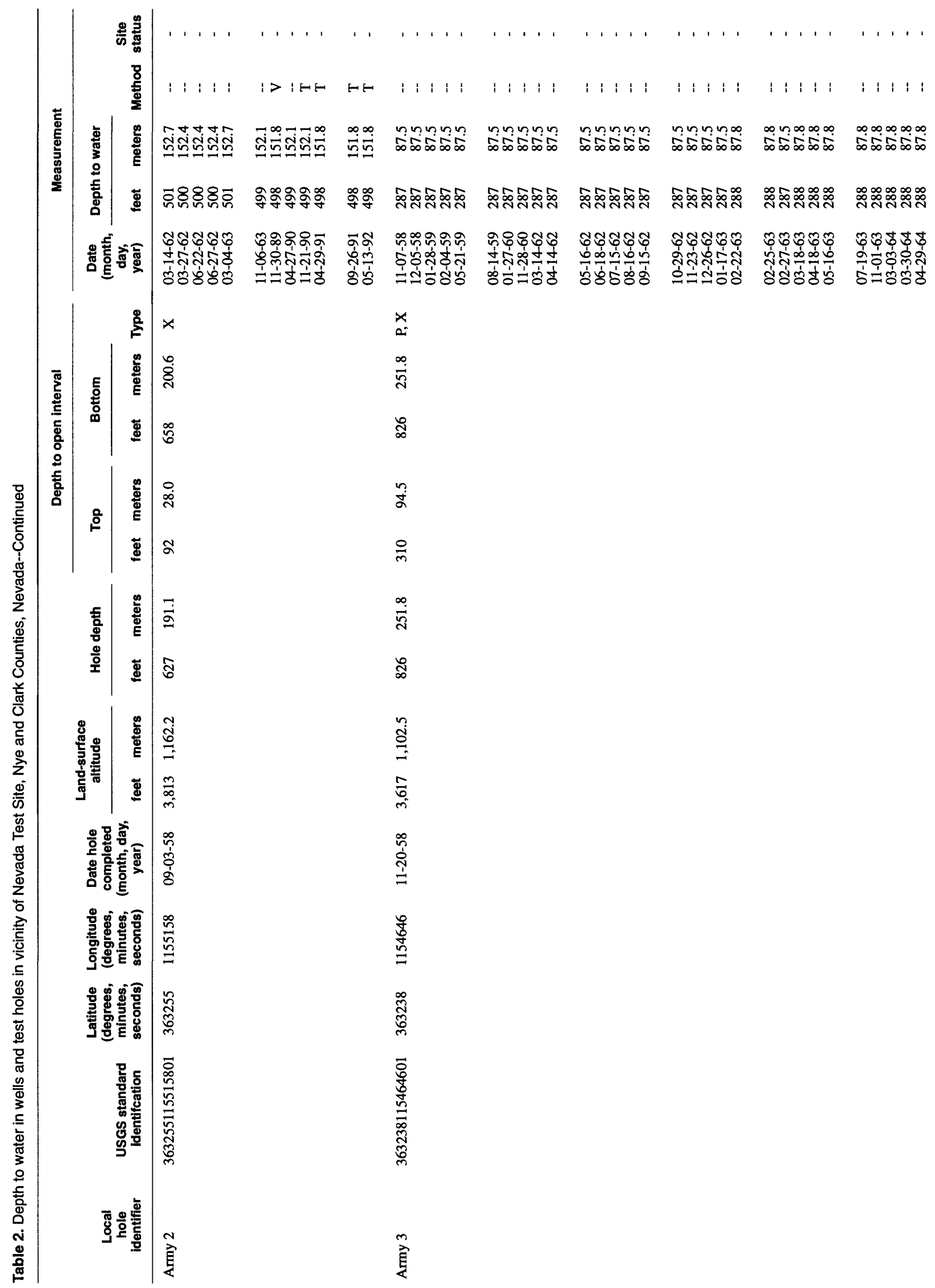




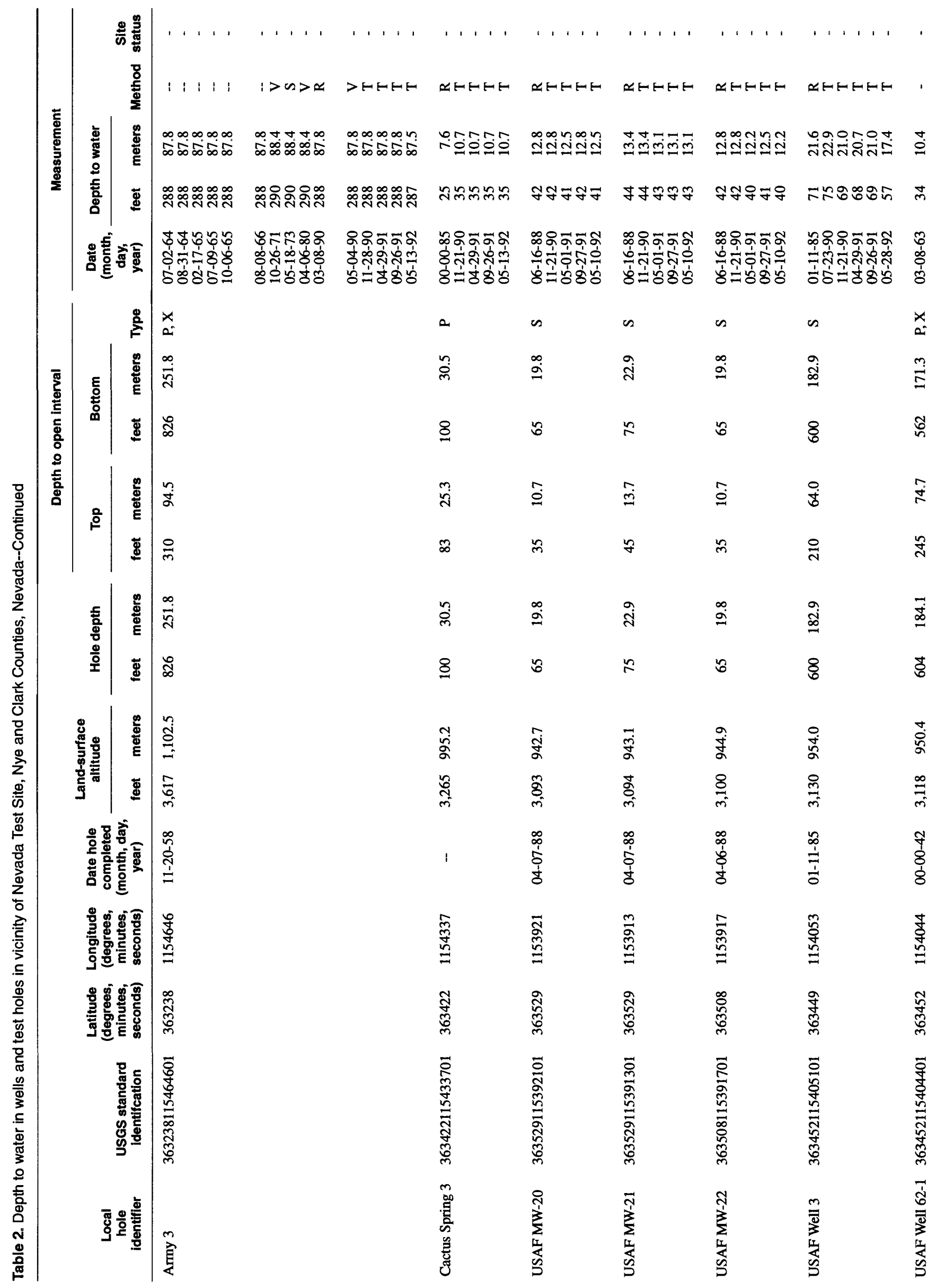




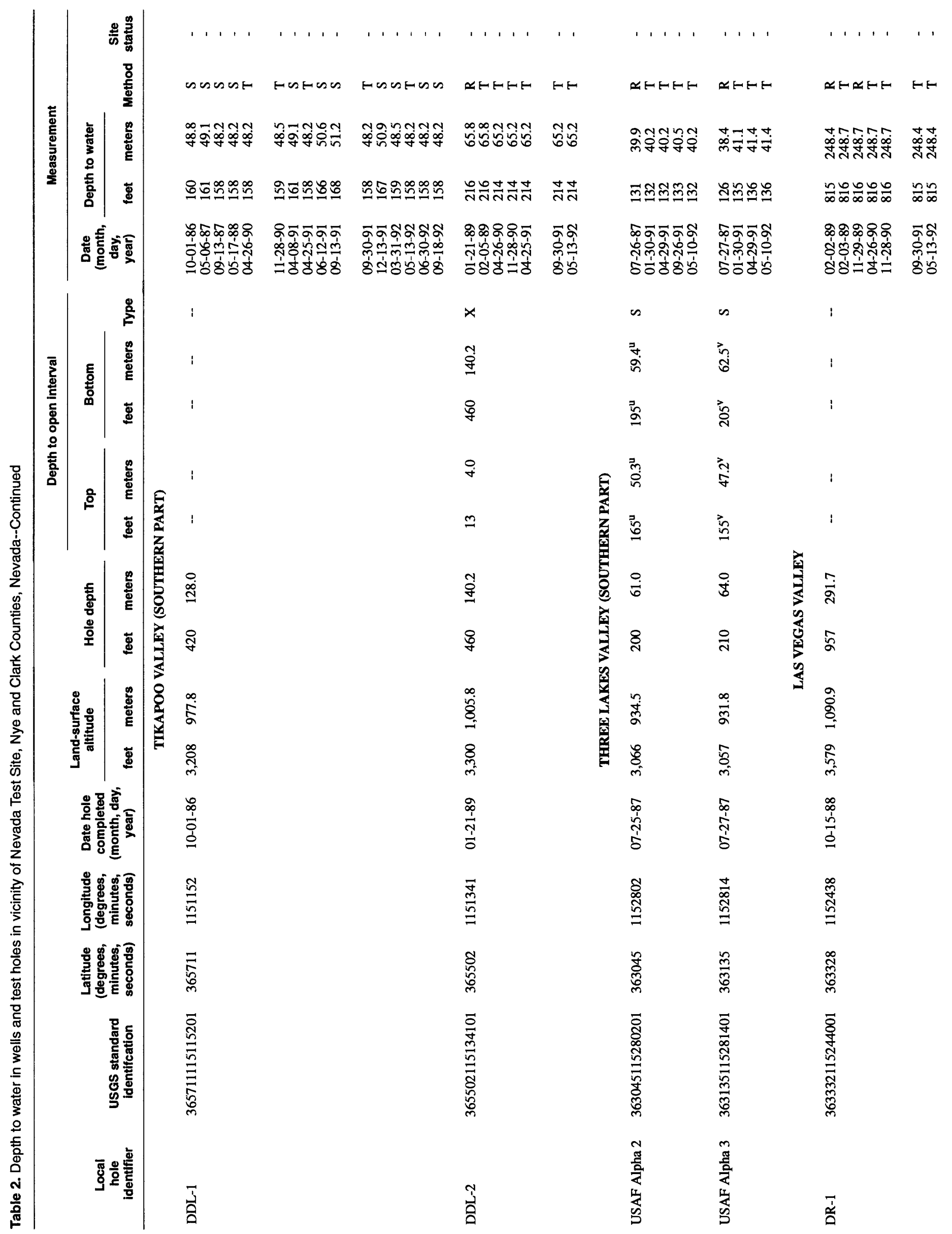




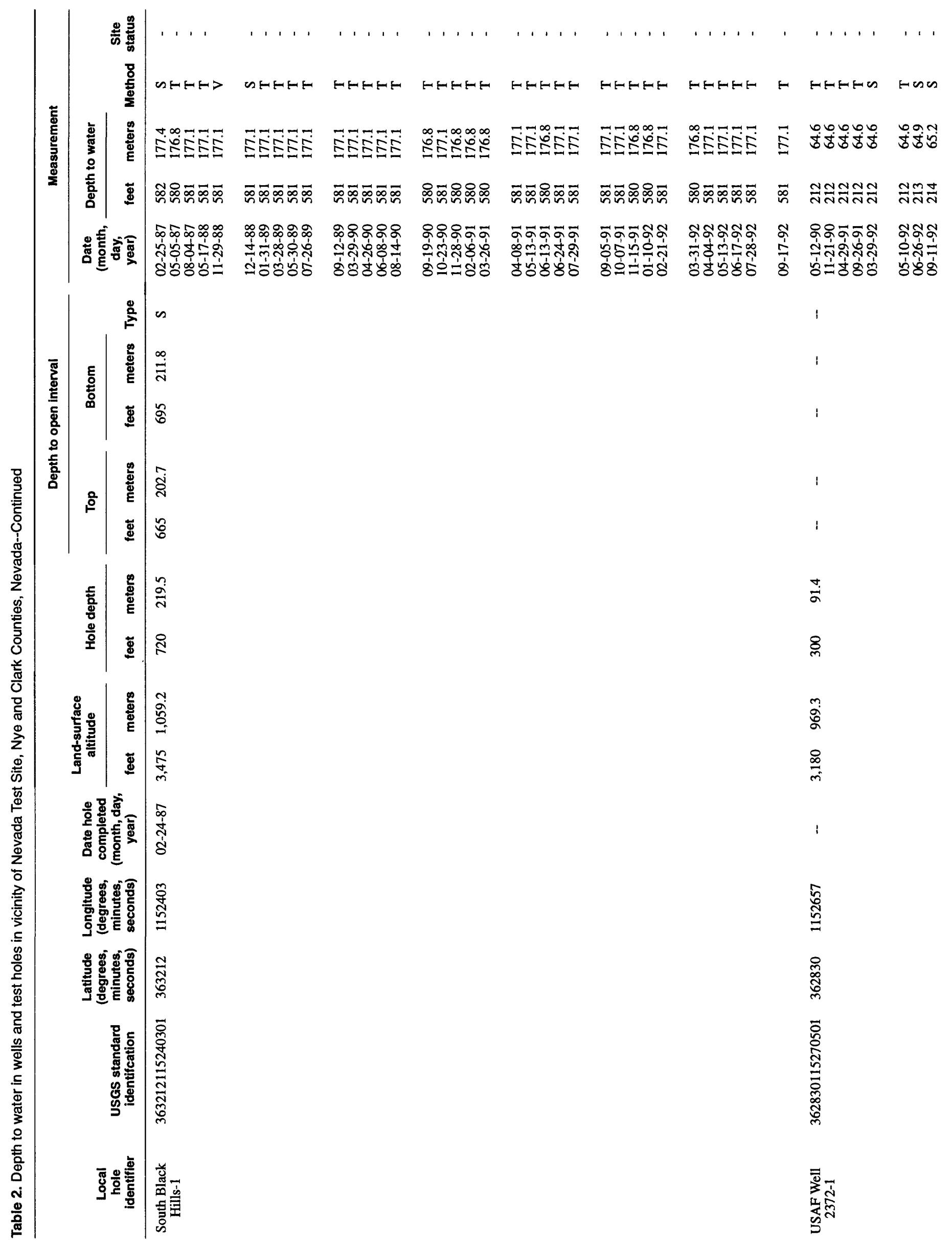




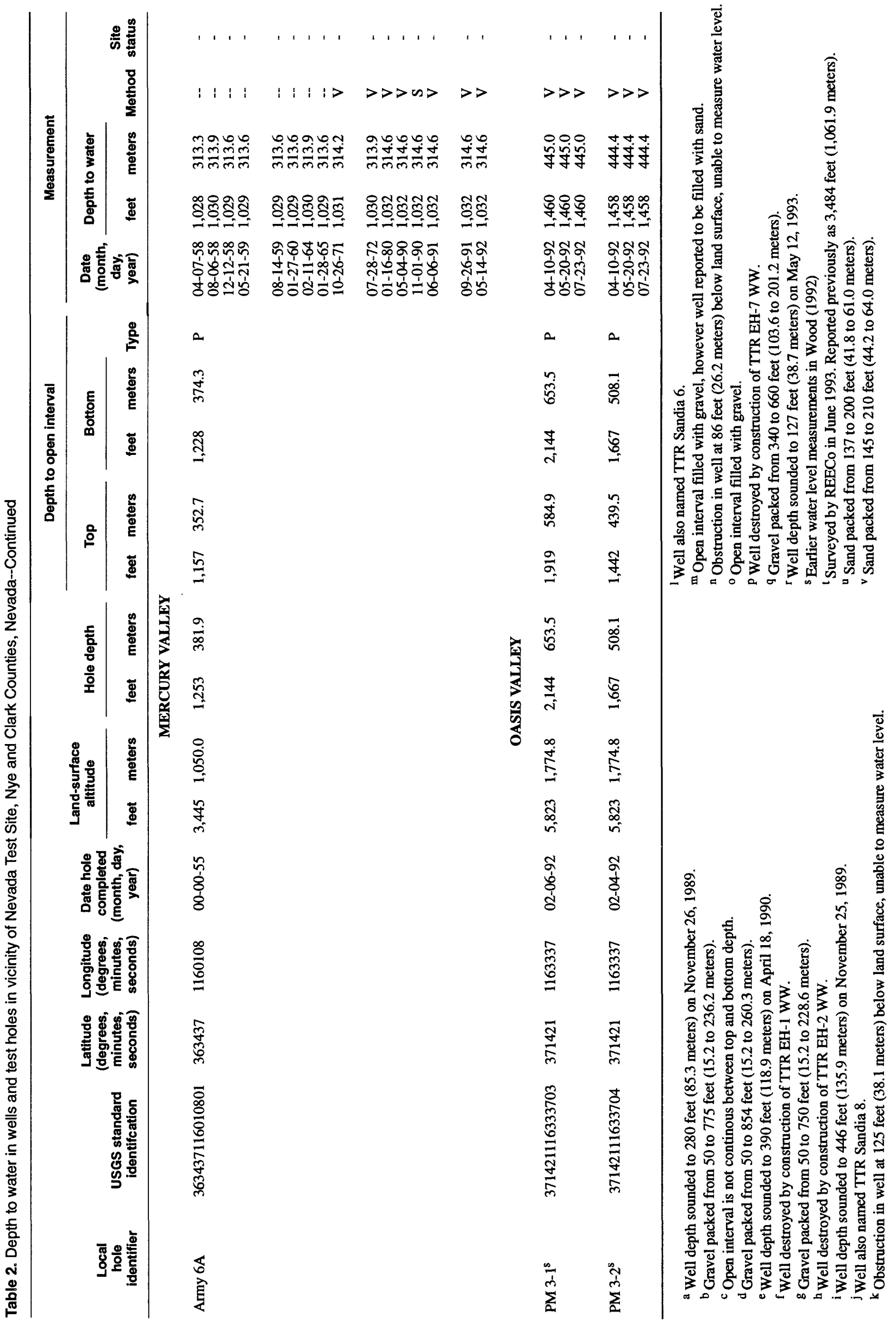



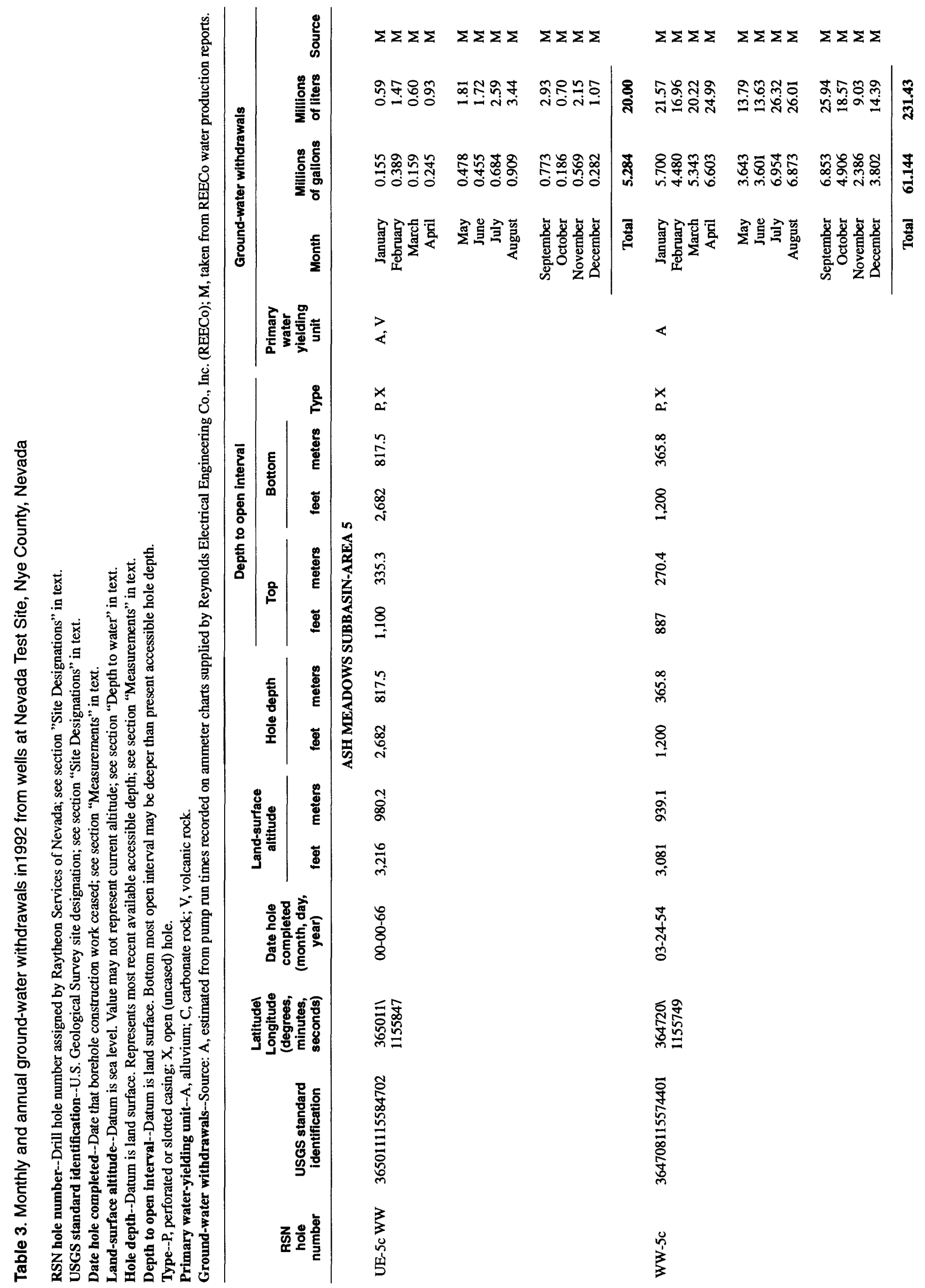


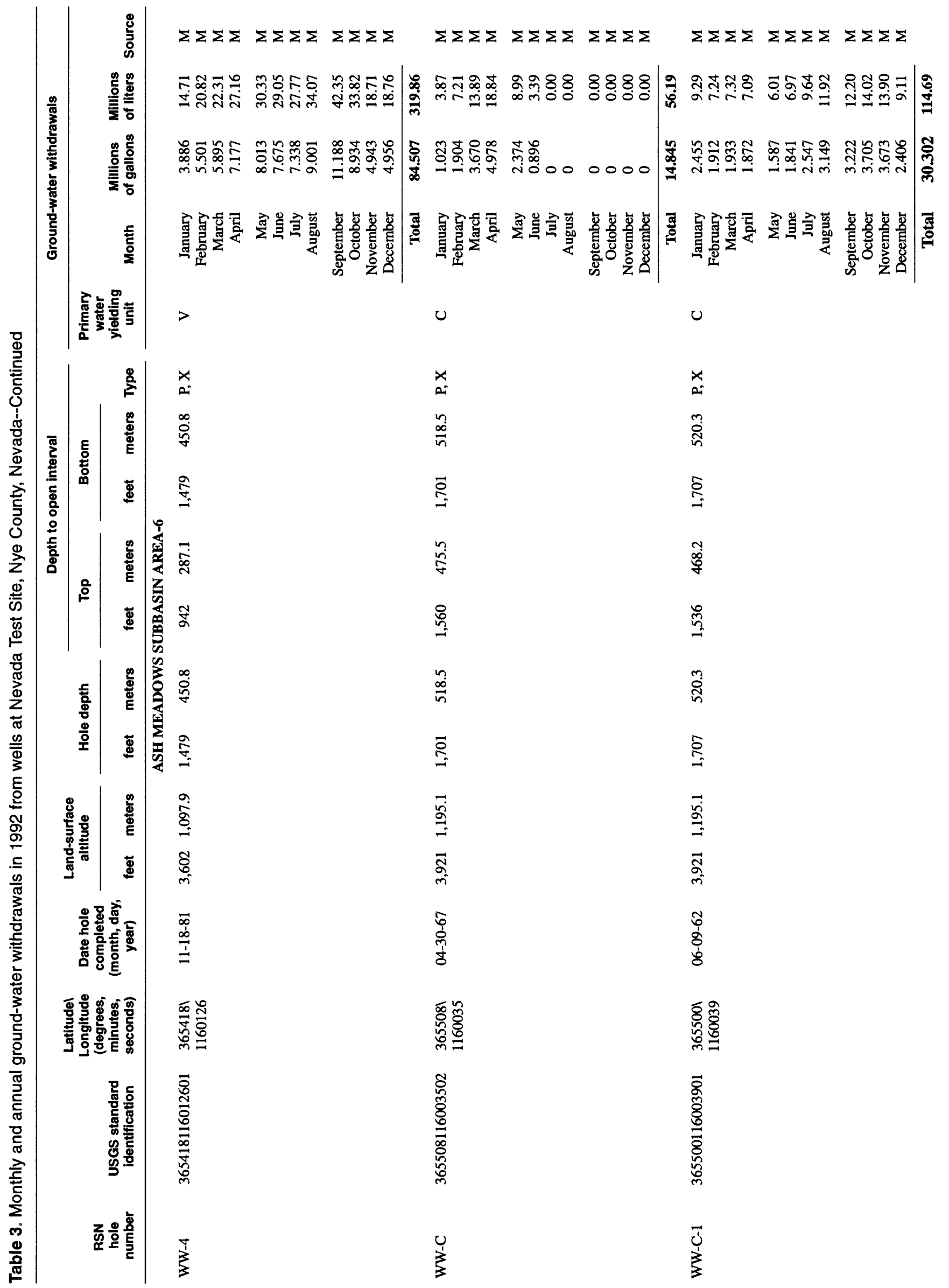




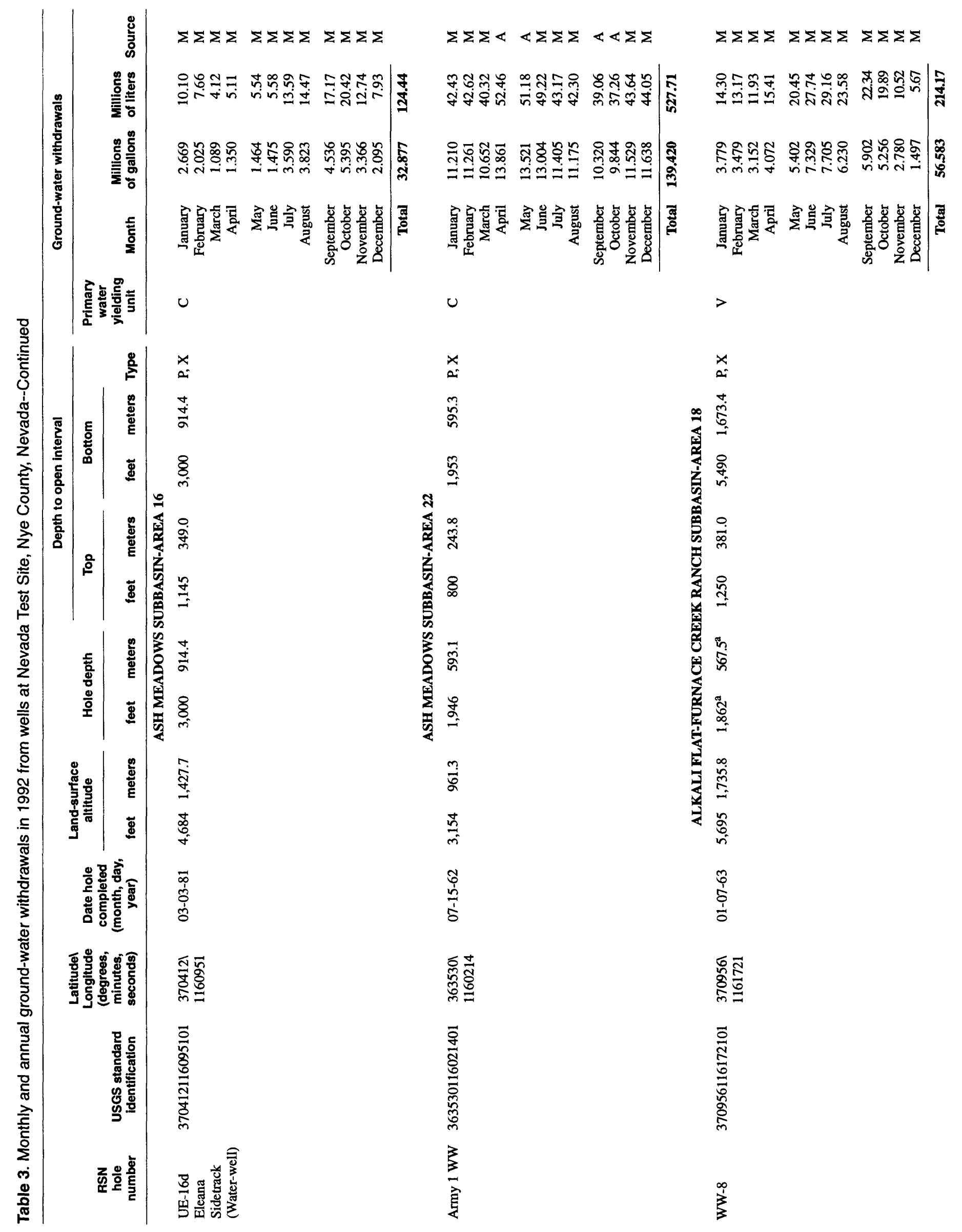




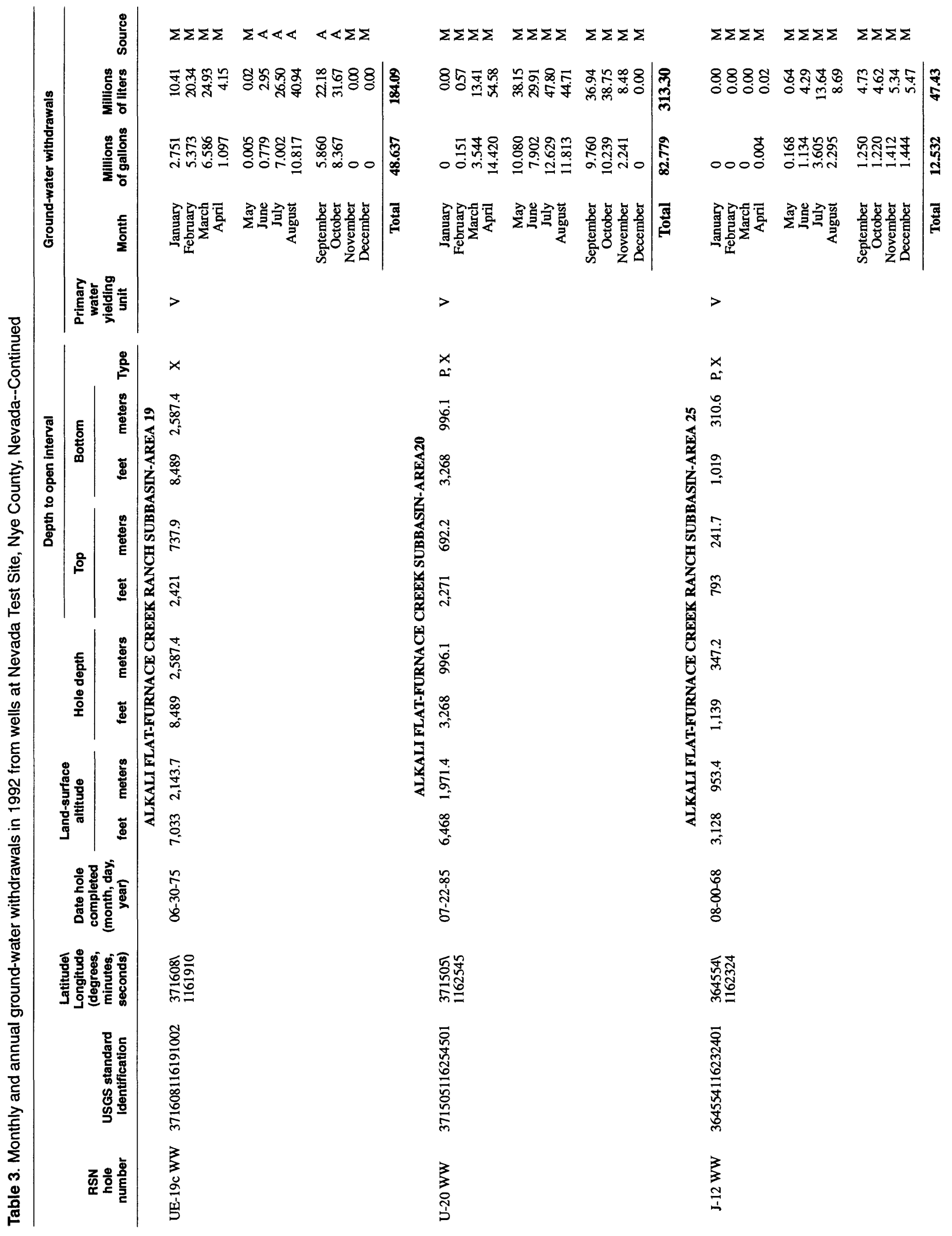




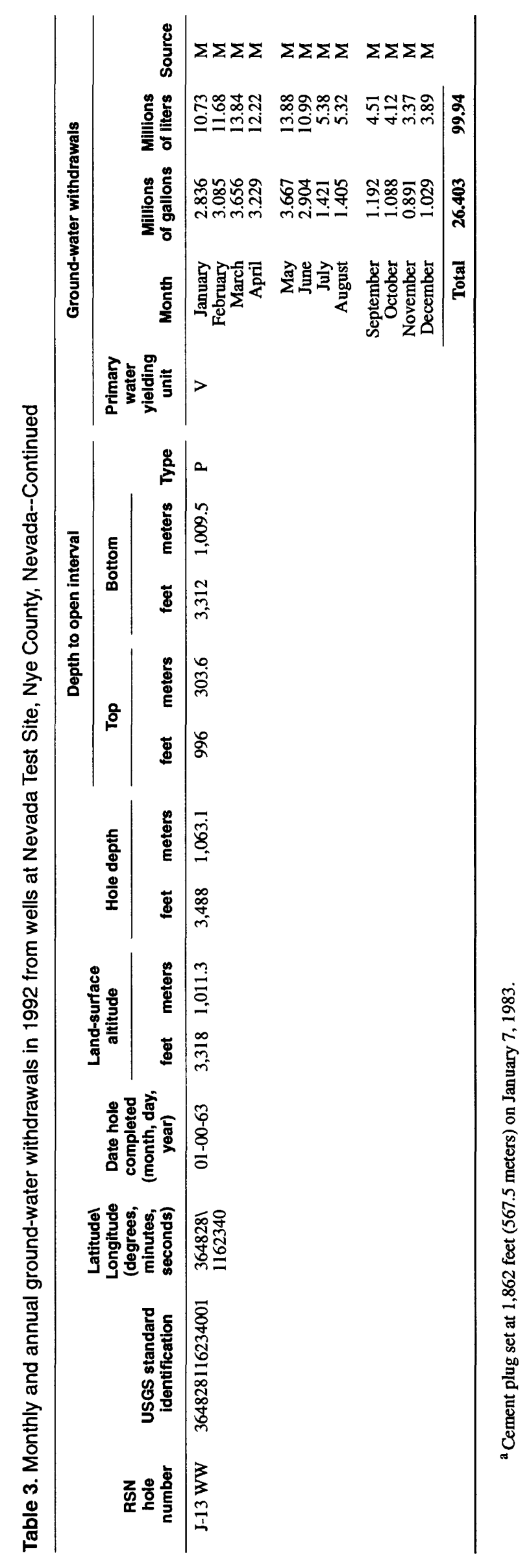




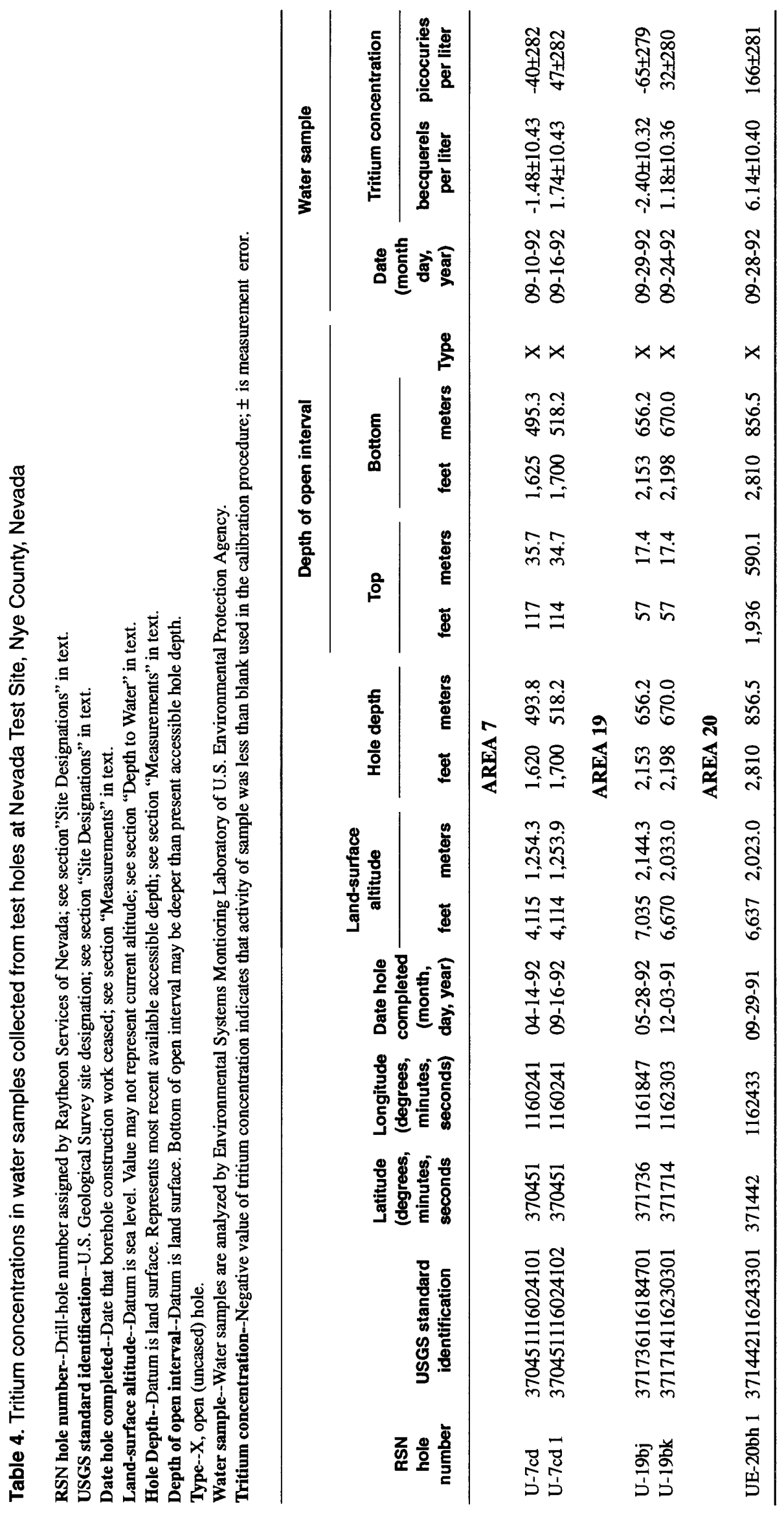

